\title{
The Impact of Auditors' Cognitive Styles on Fraud Risk Assessment (A Test of Gregorc's Energy Theory)
}

\author{
Reza Nemati koshteli \\ PhD. Student of Accounting, South Tehran Branch, Islamic Azad University, \\ Tehran, Iran \\ nematikoshteli20@yahoo.com \\ Mohsen Hamidian* \\ Assistant Professor, Depatement of Accounting, South Tehran Branch, Islamic Azad \\ University, Tehran, Iran (Corresponding Author) \\ hamidian_2002@yahoo.com \\ Seyedeh Mahboobeh Jafari \\ Assistant Professor, Depatement of Accounting, South Tehran Branch, Islamic Azad \\ University, Tehran, Iran \\ jafari.mahboobeh@gmail.com \\ Maryam sarraf \\ Assistant Professor, Depatement of Psychology, Basir Institute of Higher Education, \\ Abyek, Iran. $\underline{\text { m_sarraf50@yahoo.com }}$
}

\begin{abstract}
:
The intellectual framework of individuals is determined by their cognitive style and the cognitive style of individuals plays the role of an intermediate element between accounting information and decision making. Therefore, the purpose of this research is to investigate the effect of Gregorc's cognitive styles of auditors on fraud risk assessment. Gregorc's cognitive styles include Concrete-Sequential, abstractsequential, Concrete-random, and abstract-random styles. The statistical sample of the research consisted of 539 auditors working in the auditing institutes of the Iranian Society of Certified Auditors and the audit organization located in the geographical area of Tehran in 2019 which were selected using simple random sampling. The research method is a descriptive survey and the instrument used in the research is the standard questionnaire. Structural equation modeling using Lisrel software was used to analyze the data and test the hypotheses. The results of the analysis and findings indicate that auditors' cognitive styles have a significant effect on fraud risk assessment at a 99\% confidence level. Therefore, abstract-random, abstract-sequential, Concrete-Sequential, and Concrete-random cognitive styles have the greatest impact on fraud risk assessment, respectively. The results of
\end{abstract}


Semiannually journal of Value \& Behavioral Accounting dot 10.29252/aapc.5.9.33

this research can lead to the expansion of topics related to judgment and decision making in auditing and finally to improve audit quality.

Keywords: Fraud Risk Assessment, Cognitive Styles, Gregorc's Method, Auditors..

\section{Copyrights c) (1)(}

This license only allowing others to download your works and share them with others as long as they credit you, but they can't change them in any way or use them commercial. 


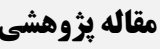

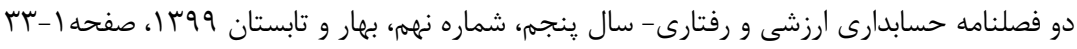

\section{تأثير سبك هاى شناختى حسابرسان بر ارزيابى ريسك تقلب

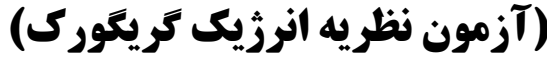

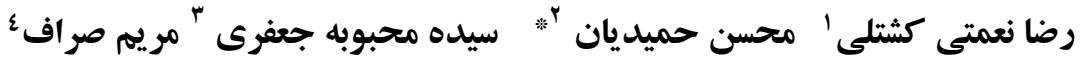

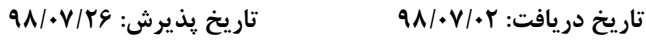

جار جوب فكرى افراد به واسطه سبك شناختى آنان تعيين مى شود و سبك شناختى افراد نقش يك عنصر واسط بين اطلاعات حسابدارى و تصميم گيرى را ايفا مى كند. از اينرو هدف اين اين

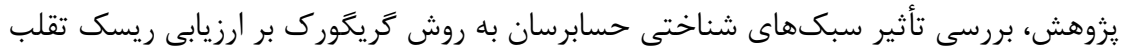

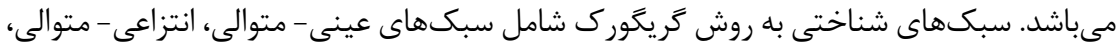

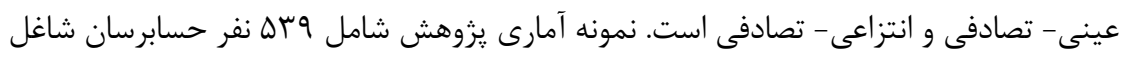

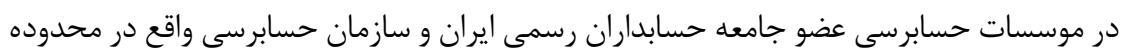

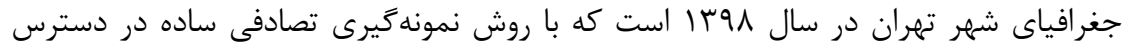

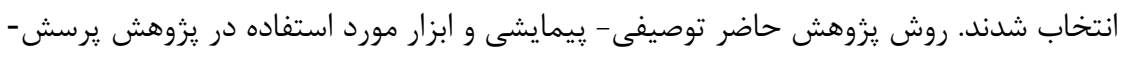

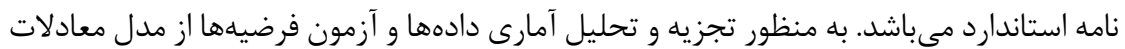
ساختارى به كمك نرم افزار ليزرل استفاده شده است. نتايج تجزيه و تحليل و يافتهها بيانكر اين

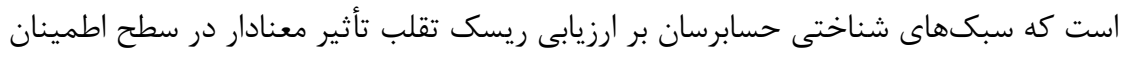

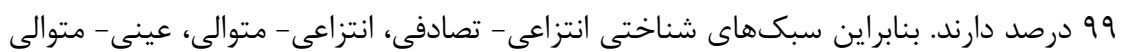

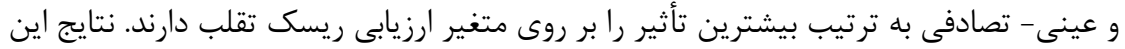

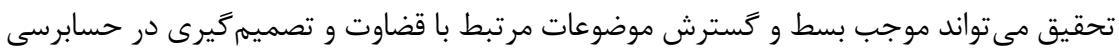
و نهايتاً ارتقاء كيفيت حسابرسى گردد. كليد وازه ها: ارزيابى ريسك تقلب، سبكهاى شناختى، روش كريخورى، حسابرسان. 'دانشجوى دكترى كروه حسابدارى، واحد تهران جنوب، دانشَاه آزاد اسلامى، تهران، ايران nematikoshtelir·@yahoo.com "آستاديار كروه حسابدارى، واحد تهران جنوب، دانشكاه آزاد اسلامى، تهران، ايران (نويسنده مسئول) hamidian_r.r.r@yahoo.com

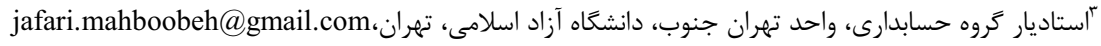

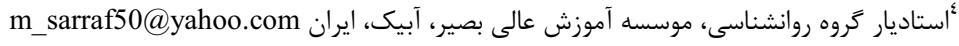




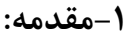

رخداد تقلبهاى اخير در ايران با تمام تبعات منفى اقتصادى، سياسى و اجتماعى و اثرات

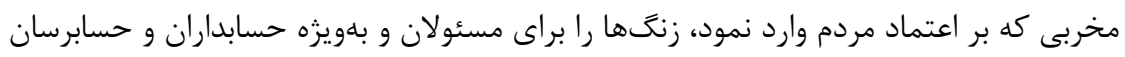

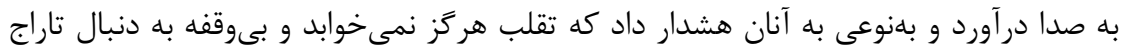

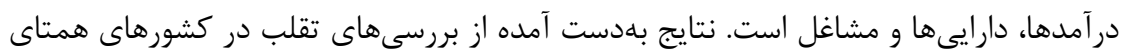

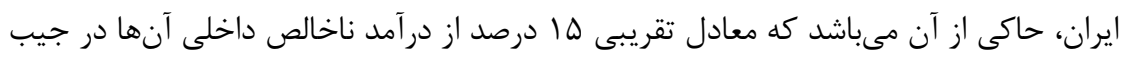

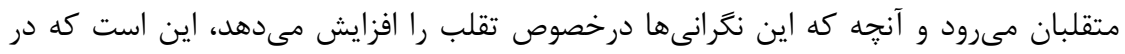

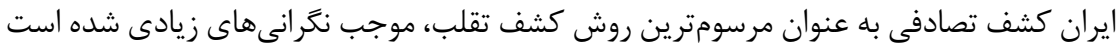

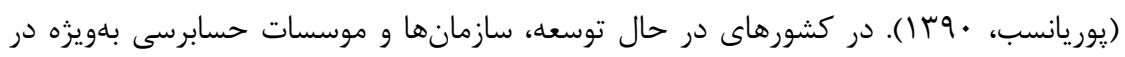

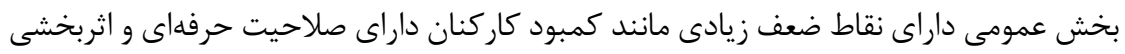

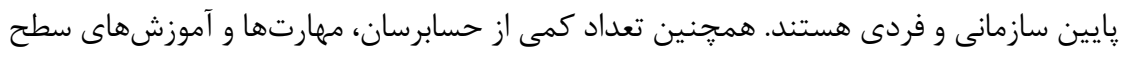

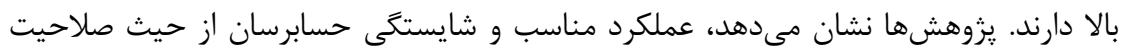

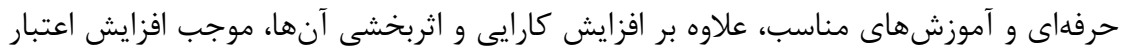

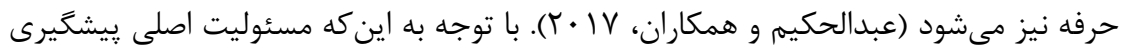

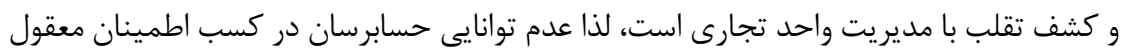

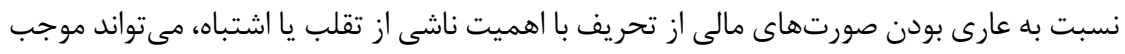

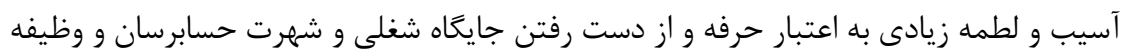

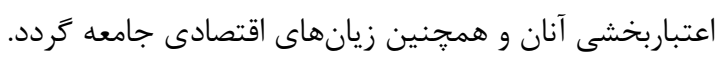

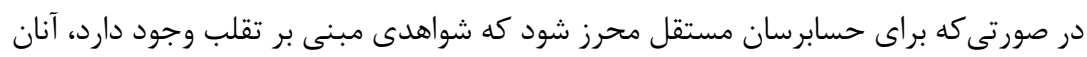

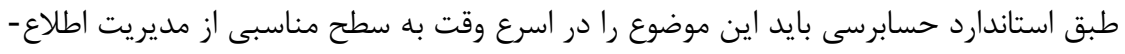

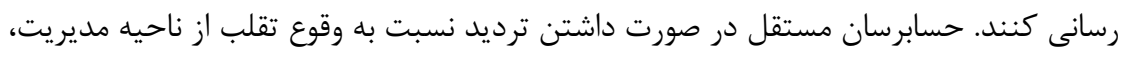

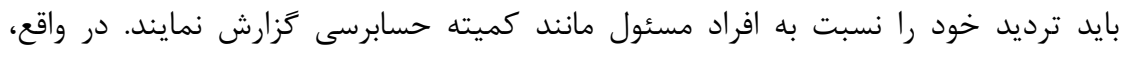

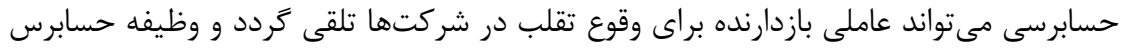

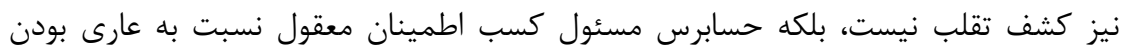

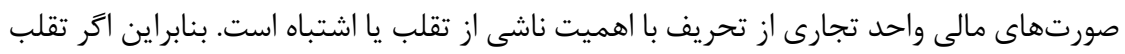

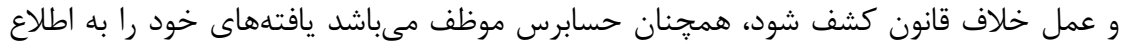

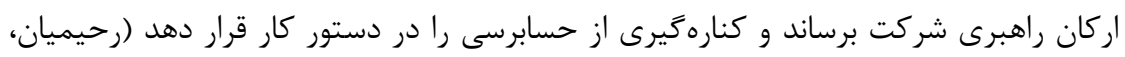

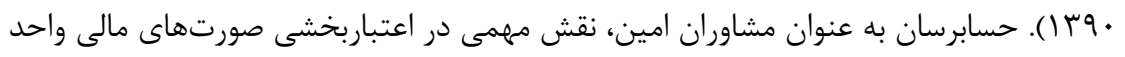

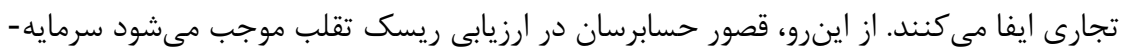

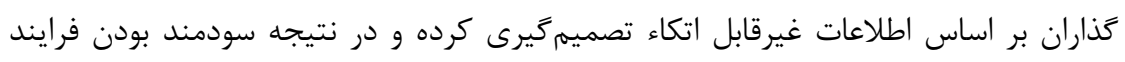




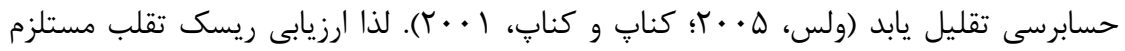

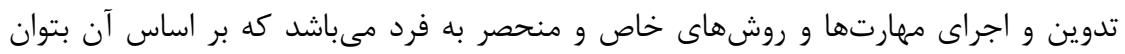

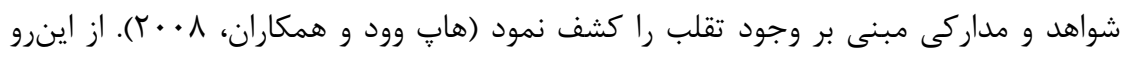

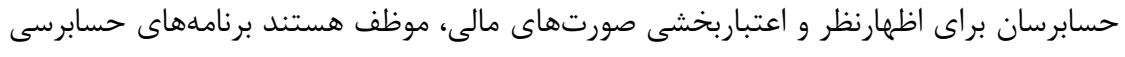

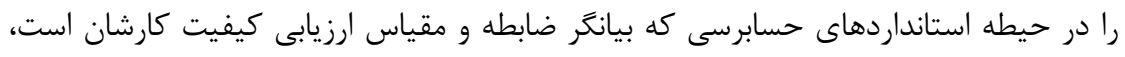

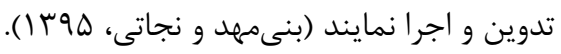

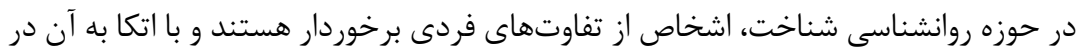

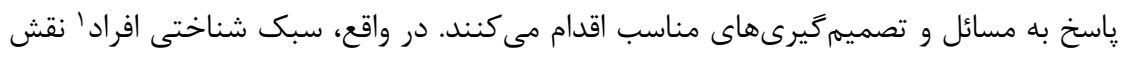

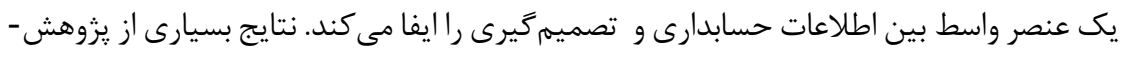

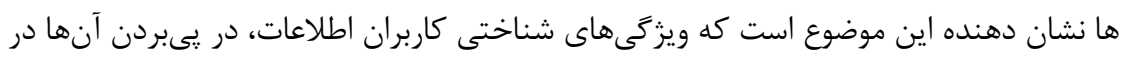

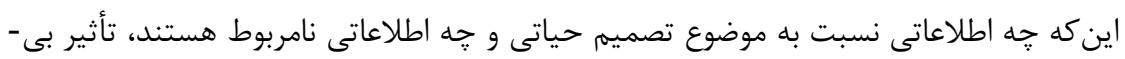

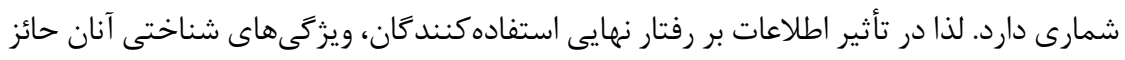

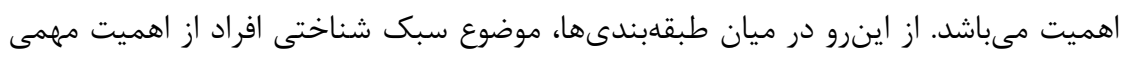

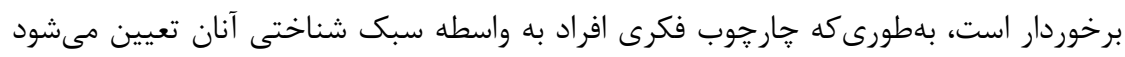

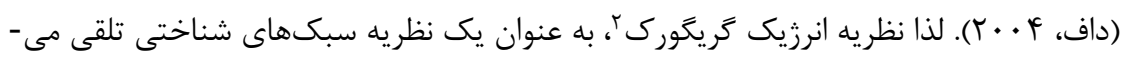

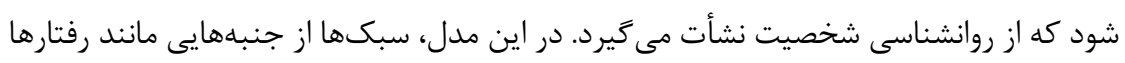

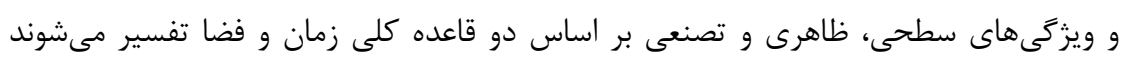

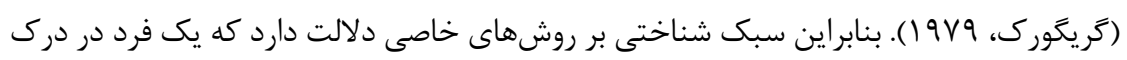

$$
\text { و مفهومسازى محيط به كار مى كيرد. }
$$

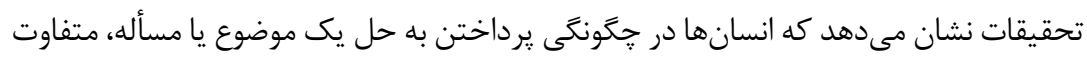

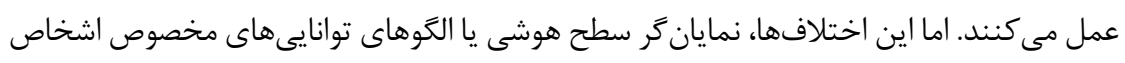

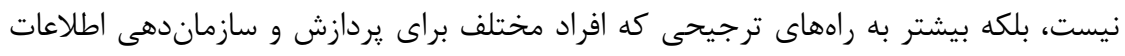

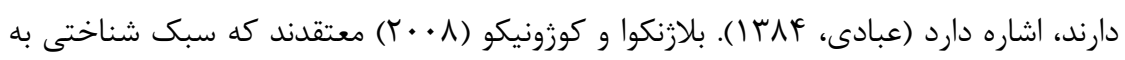

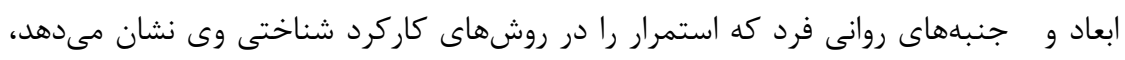

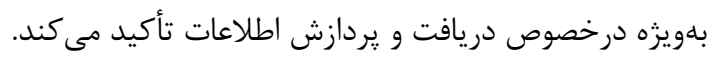

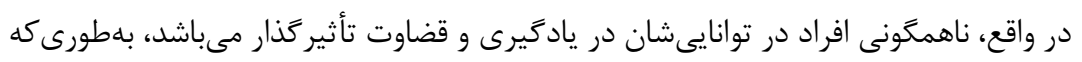

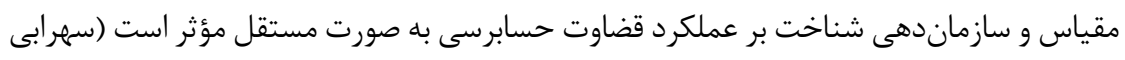

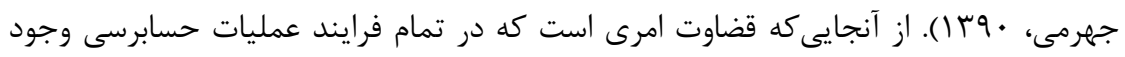

${ }^{1}$ Cognitive Style of individuals

${ }^{2}$ Gregorc's Energy Theory 


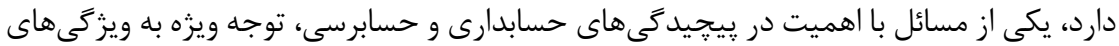

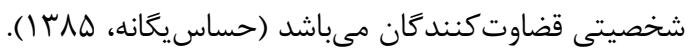

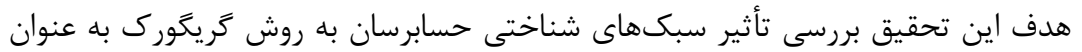

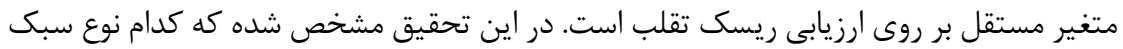

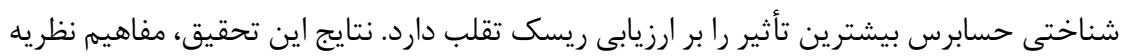

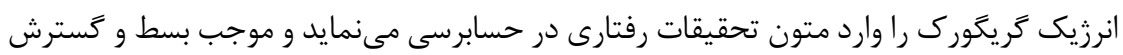

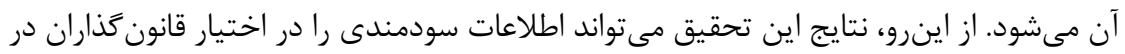

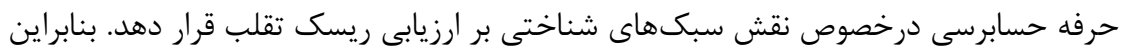

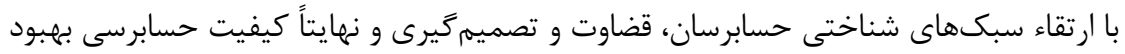

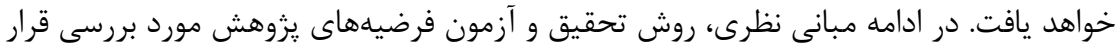

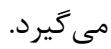

\section{r- مبانى نظرى و پييشينه يزوهش

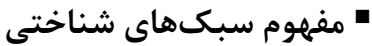

اصطلاح سبك، بلعنوان الكوى عادتى يا روش ترجيحى براى انجام يك كار تعريف مىشود

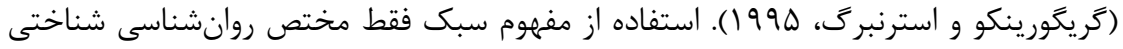

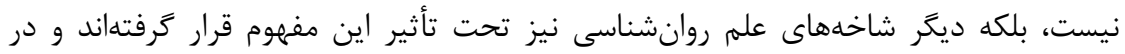

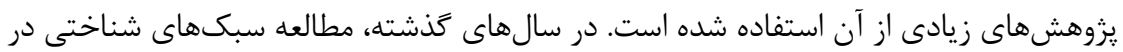

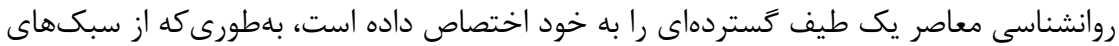

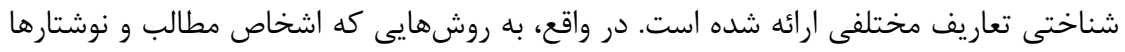

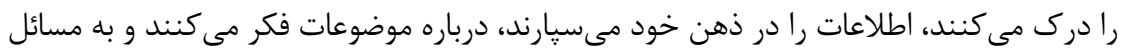

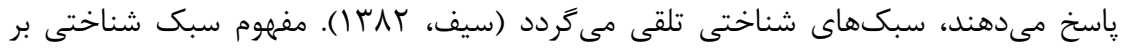

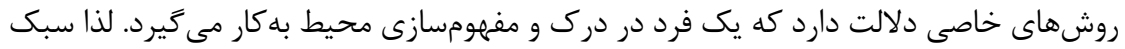
شناختى فرآيندى است كه افراد از طريق آن اطلاعات را الز محيط يُ ديرامون كسب و و تفسير نموده

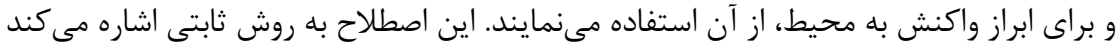

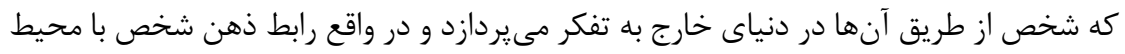

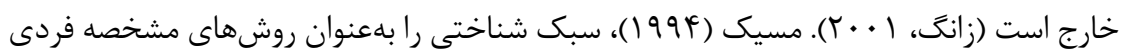

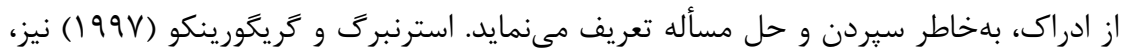

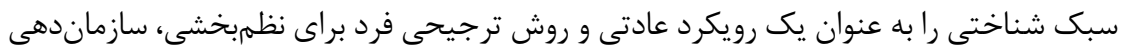

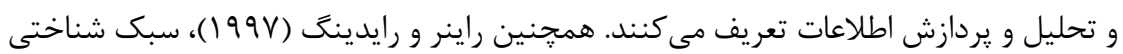


را به عنوان يك روش درونى و خودكار جهت حل مسأله، پاسخدهى به اطلاعات و موقعيتها تفسير مى كنند.

\section{• تفاوت سبكهاى شناختى با سبكهاى يادكيرى}

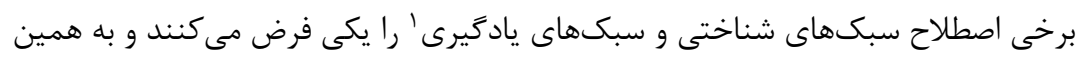

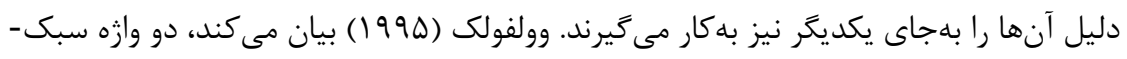

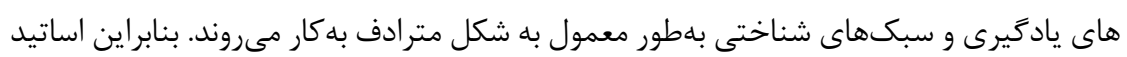

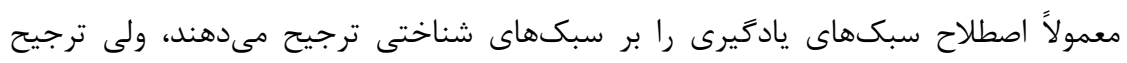

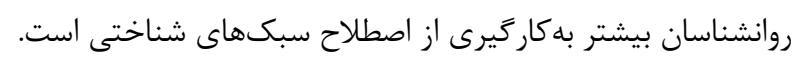

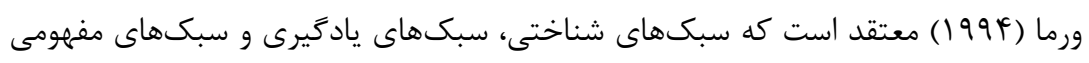

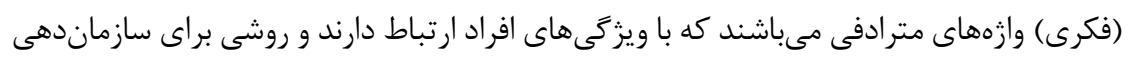

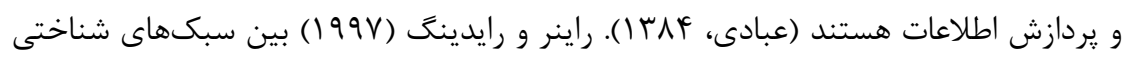

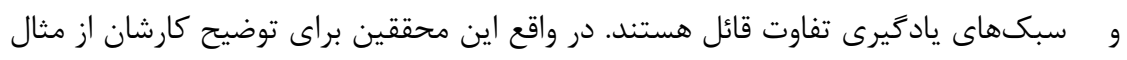

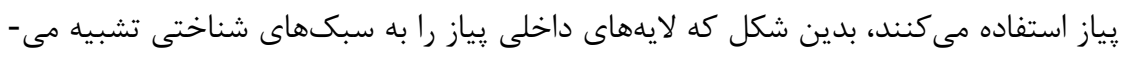

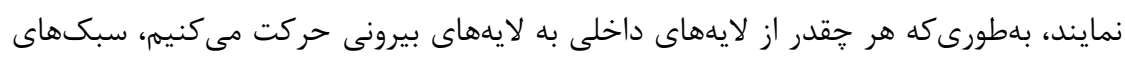

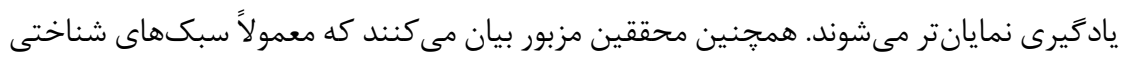

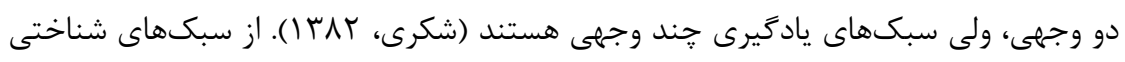

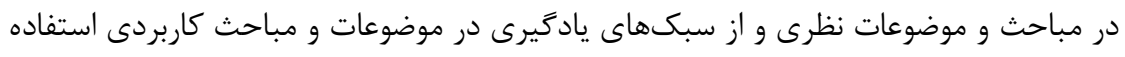

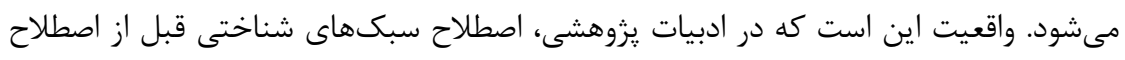

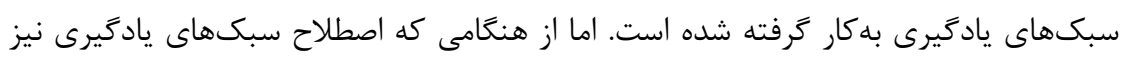

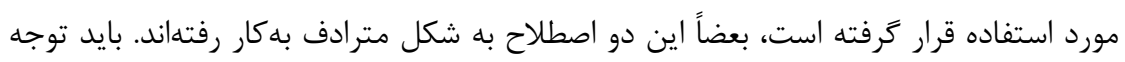

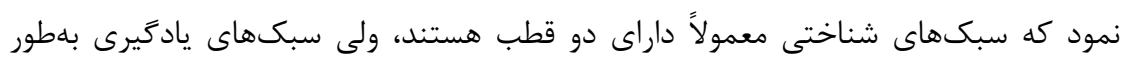

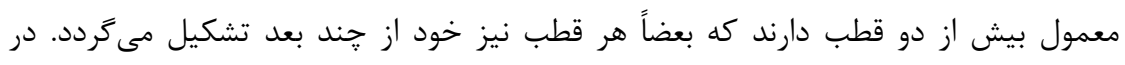

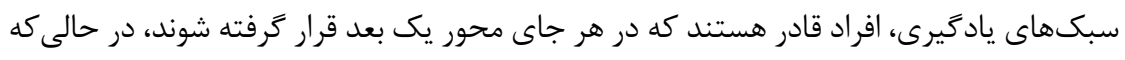

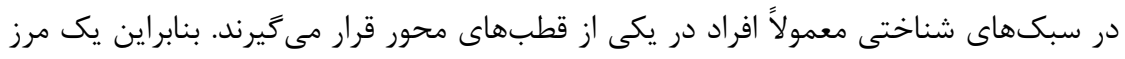

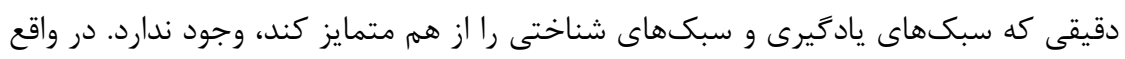

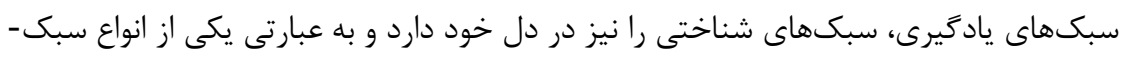

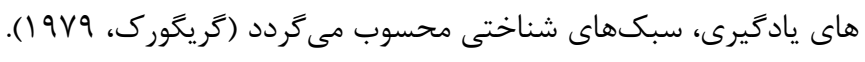

\footnotetext{
${ }^{1}$ Learning Styles
} 


\section{• سبكهاى شناختى (نظريه انرزيك) تريكورك}

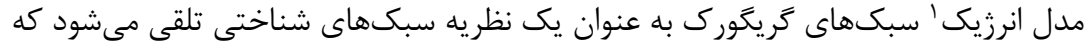

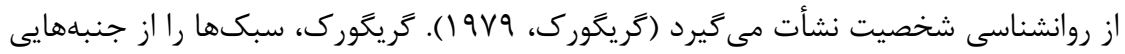

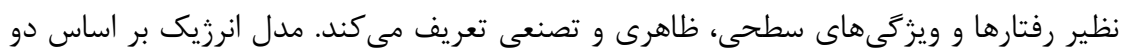

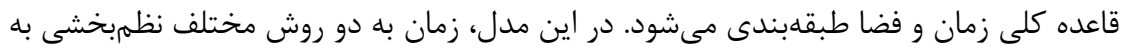

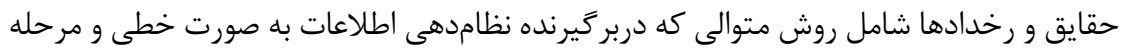

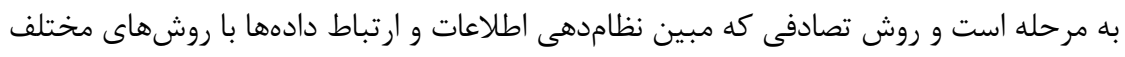

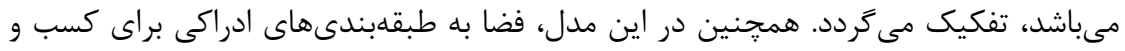

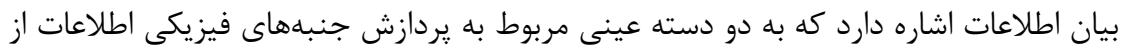

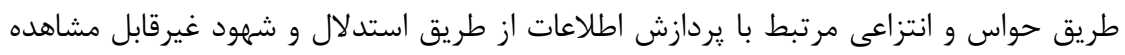

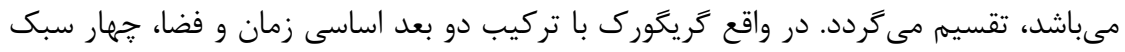

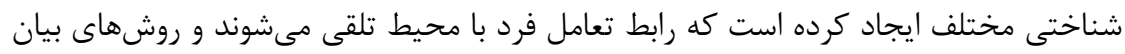

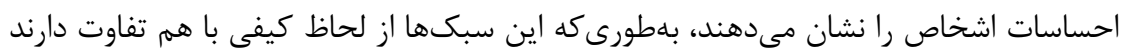

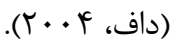

كريخور ك معتقد است يادَيرى افراد به واسطه تجارب عينى و انتزاعى به روشهادى متوالى

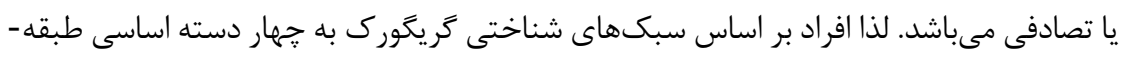
بندى مىشوند كه عبارتند ازي

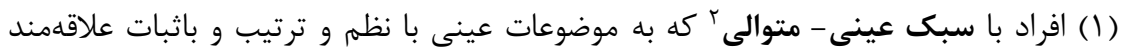

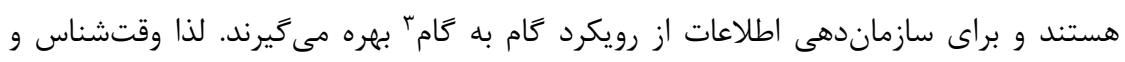

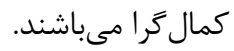
(Y) افراد با سبك انتزاعى - متوالى كُ كه در كلام قوى هستند. دوست دارند بخوانند، كوش دهند

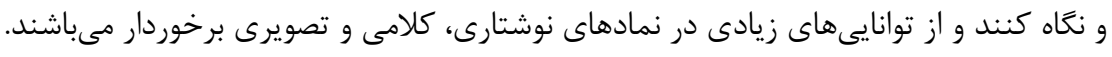

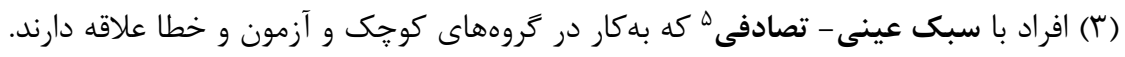
مخاطره جو، رهبر و شهودى هستند و دوست دارند خود مسئوليت امور را بر عهده بخيرند.

${ }^{1}$ Energy Model

${ }^{2}$ Concrete-Sequential

${ }^{3}$ Step by Step Approach

${ }^{4}$ Abstract-Sequential

${ }^{5}$ Concrete-Random 


\begin{tabular}{|c|}
\hline دكتر حميديان و همكاران، تأثير سبك هاى شناختى حسابرسان بر ارزيابى ريسك تقلب... \\
\hline
\end{tabular}

(\&) افراد با سبك انتزاعى - تصادفى ' كه هنخام كفتخو از حر كات بدن استفاده مى كنند و ترجيح

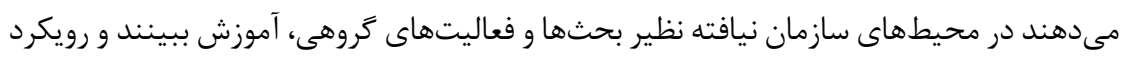

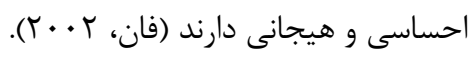

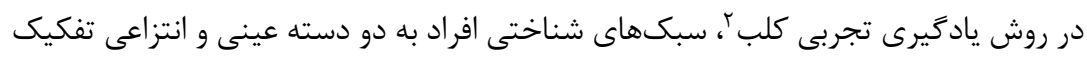

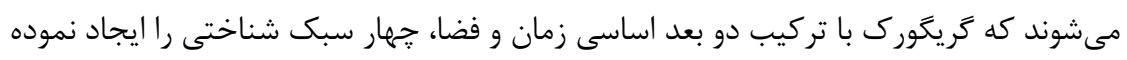

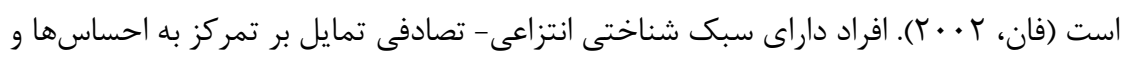

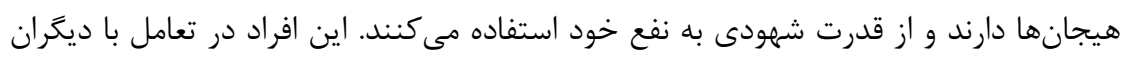

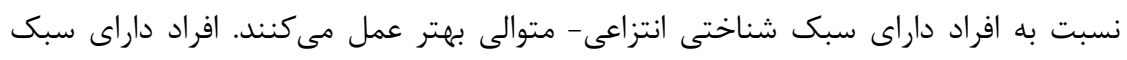

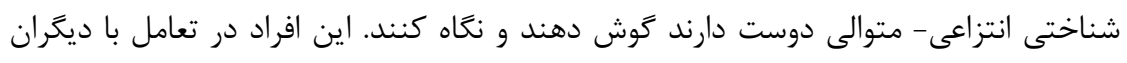

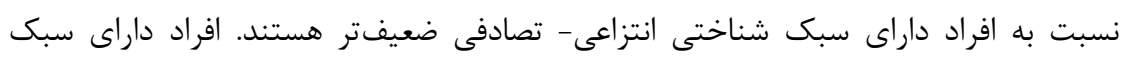

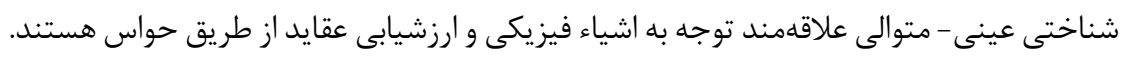

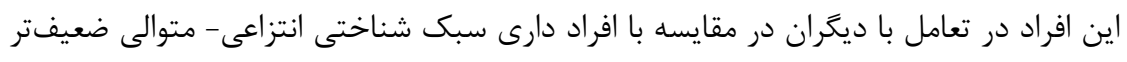

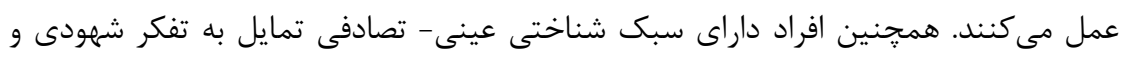

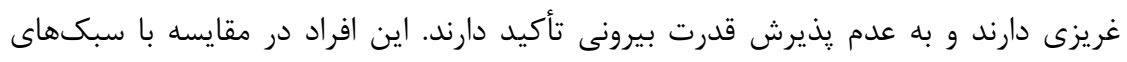

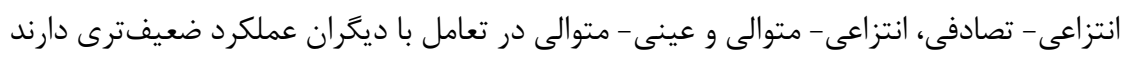

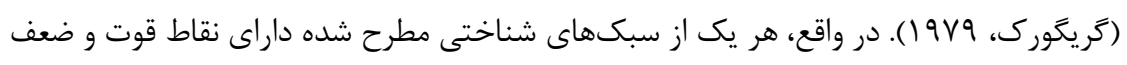

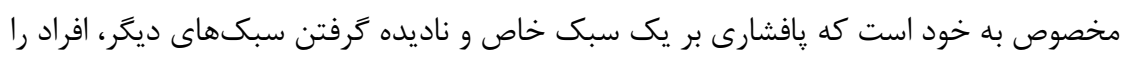

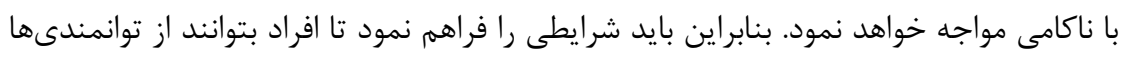
و مهارتهاى سبكهاى ديكر نيز، برخوردار شوند (كلب، ع + · ب).

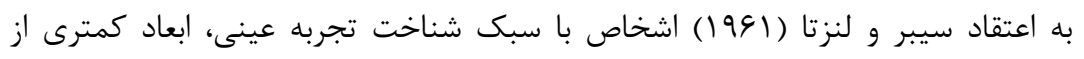

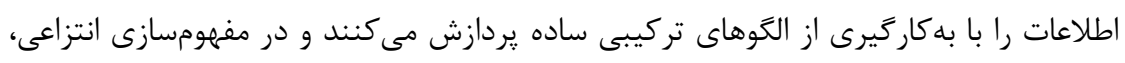

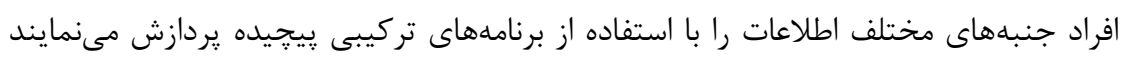

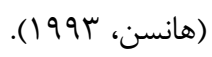
با بررسى متون مرتبط در حوزههاى حسابدارى و حسابرسى، مطالعاتى كه تاكنون صورت

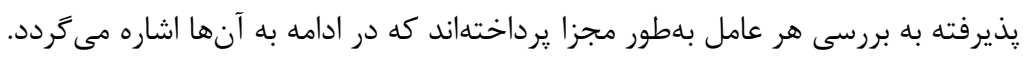

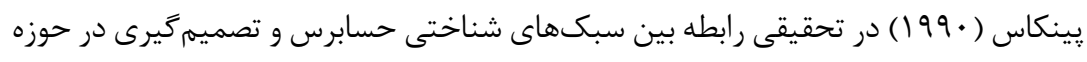

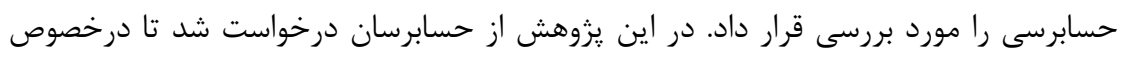

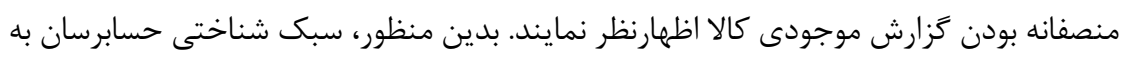

${ }^{1}$ Abstract-Random

${ }^{2}$ Kolb's Experiential Learning Method 


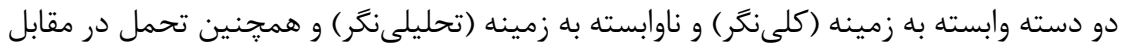

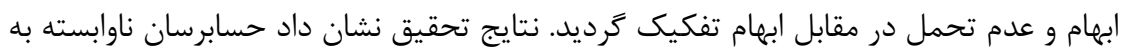

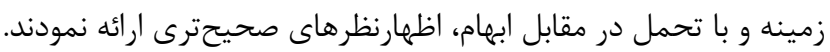

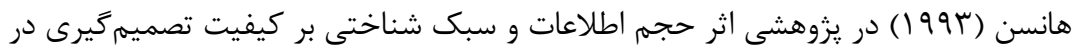

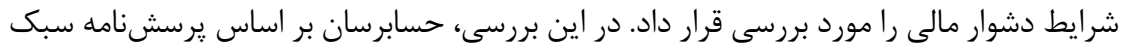

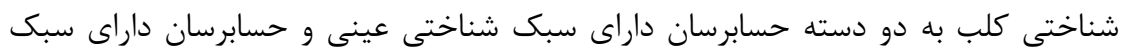

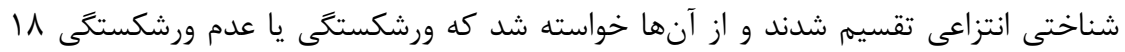

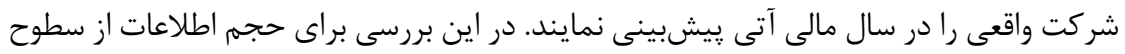

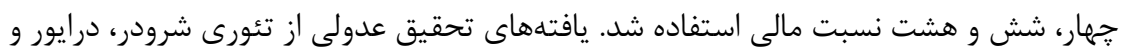
استرفر (9V9 19V9) بوده و آزمونشنودكان با اضافه بار اطلاعات مواجه نشدهاند.

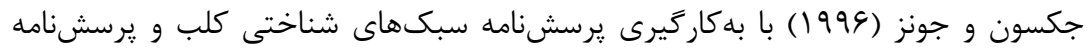

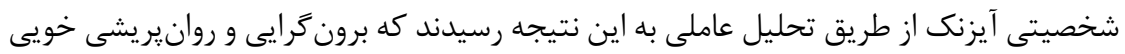
با تعدادى از مولفههاى سبكهاى شناختى كلب رابطه دارد، اما روان رنجورخويى بان با مولفههاى

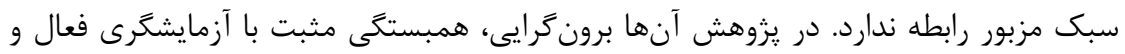

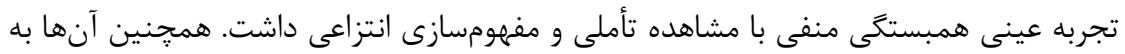

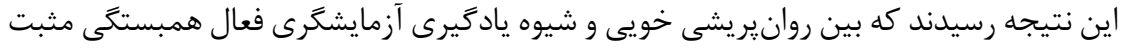

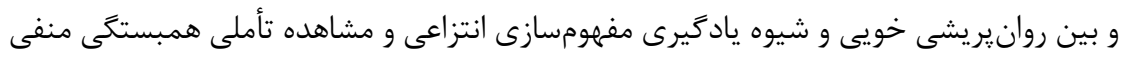
وجود دارد.

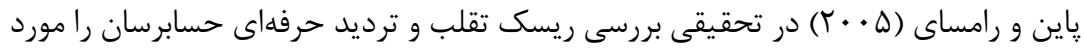

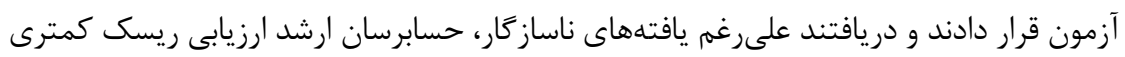

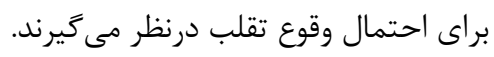

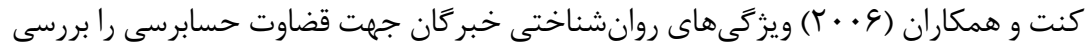

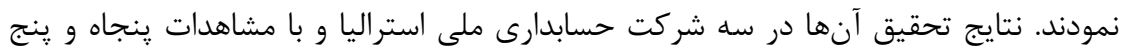

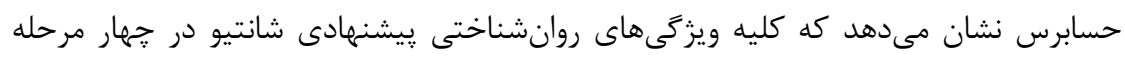

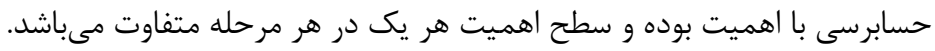

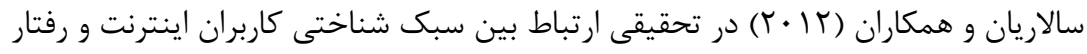

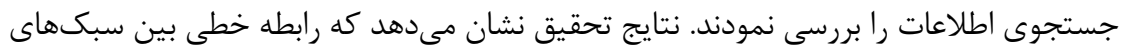

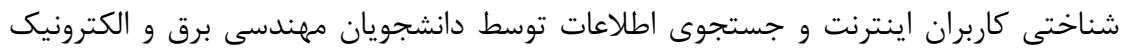
دانشعاه تكنولوزى مالزى وجود دارد. 
9 دكتر حميديان و همكاران، تأثير سبك هاى شناختى حسابرسان بر ارزيابى ريسك تقلب...

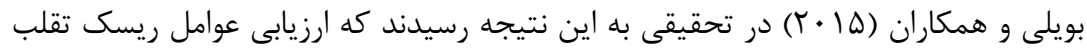

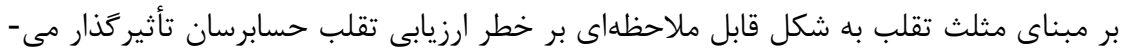

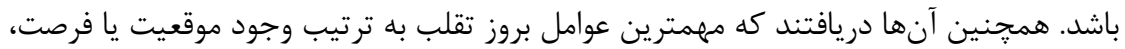
توجيه عقلانى و فشار است.

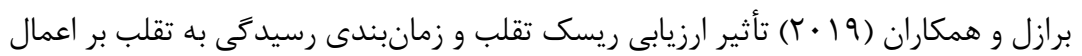
و قضاوت حسابرسان را مورد بررسى قرار دادند. نتايج حاكى از آن است، حسابرسانى كه رسيدكى رئى

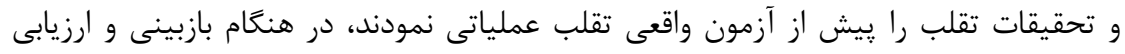

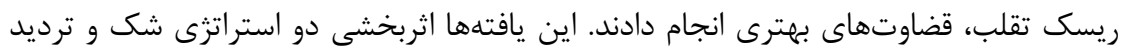

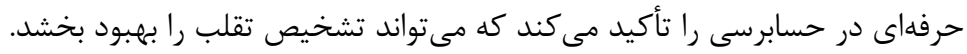

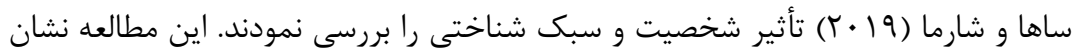

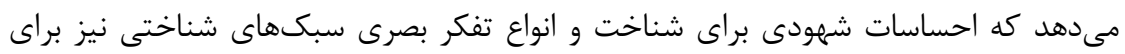

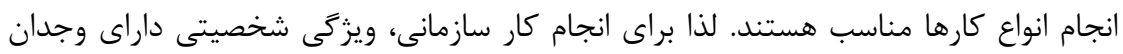
كارى براى مديران حائز اهميت است.

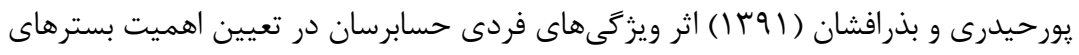

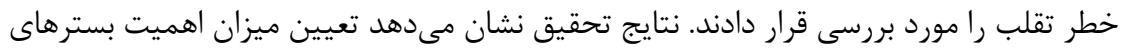

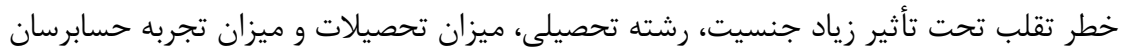

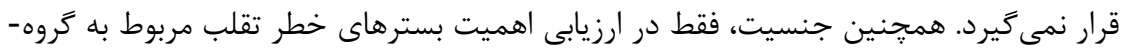

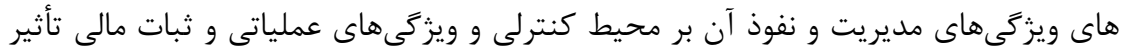

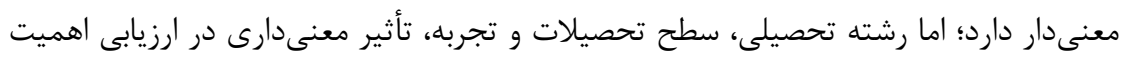

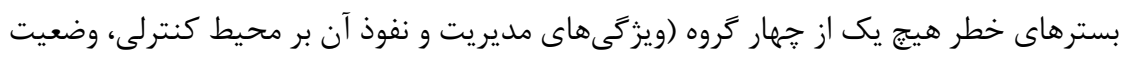

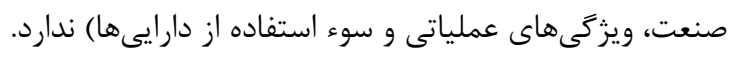

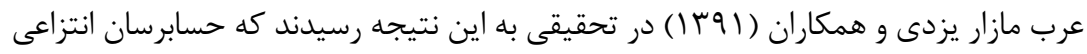

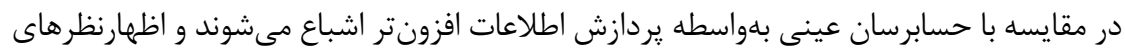

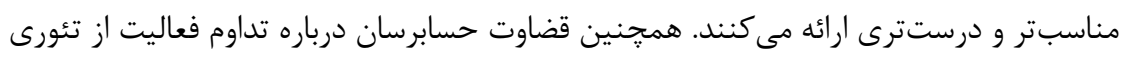

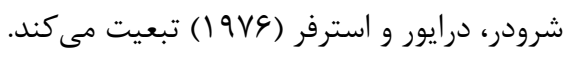

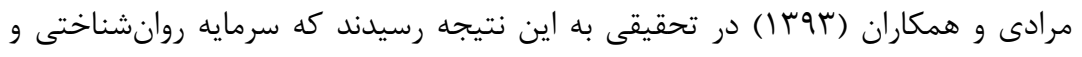

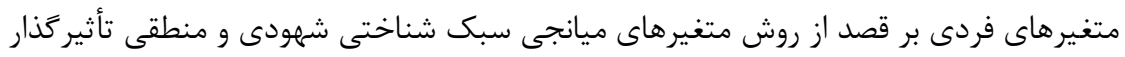

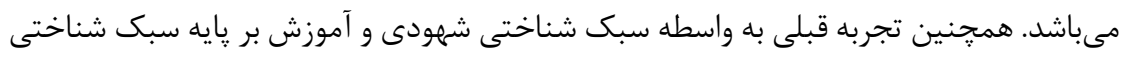
منطقى بر قصد كار آفرينانه تأثير مى تجذارد. 


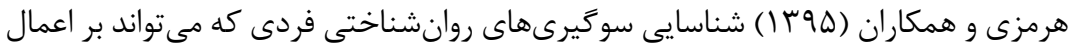

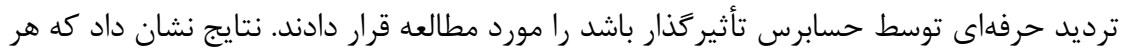

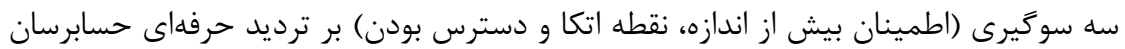

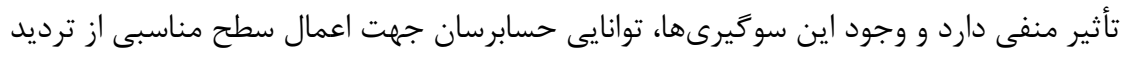
حرفهاى در فرايند حسابرسى را تقليل مى دهندئ.

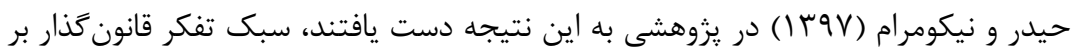

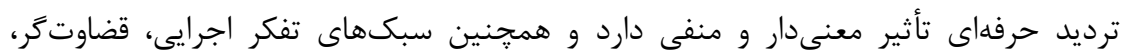

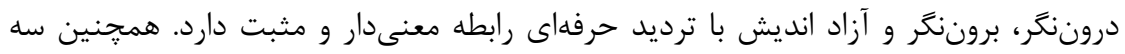

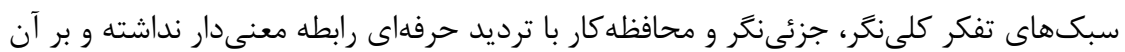
تأثير كذار نيستند.

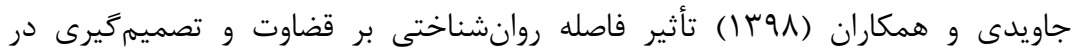
حسابدارى را بررسى نمودند. نتايج تحقيق نشان مىدهد كه قضاوت تصميمَيرندكان بانيت

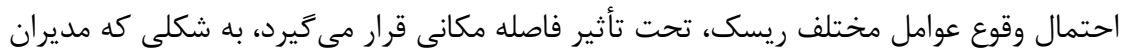

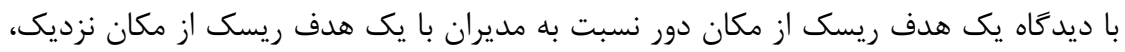

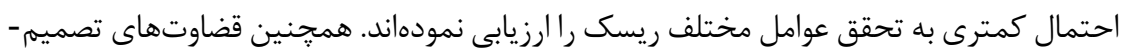

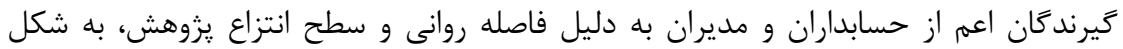

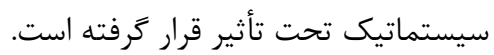

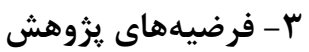

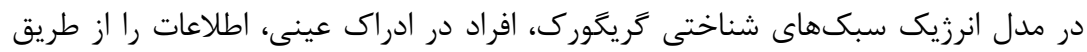

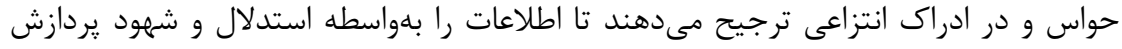

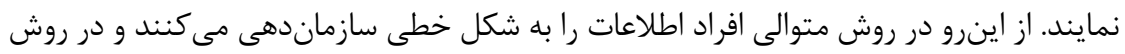

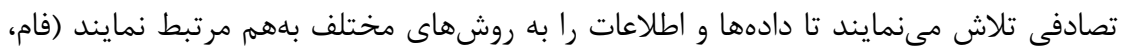

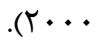
در بيشتر تحقيقات بيشين حسابدارى، از دو نوع سبك شناختى استقلال عملى در مقابل

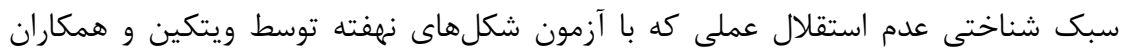

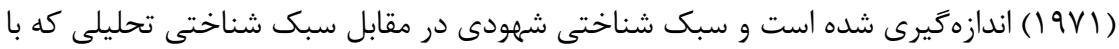

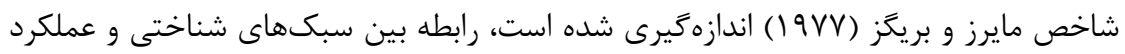
حسابرسان مورد بررسى قرار كرفته است. نتايج تحقيقات نشان مى دهد استقلال عملى به به ميزان

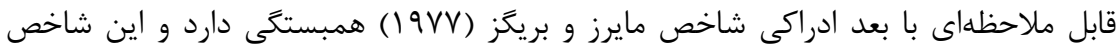


محتواى اطلاعاتى بيشترى را دربر مى گيرد. در واقع عملكرد حسابرسان در صورت وجود تطابق

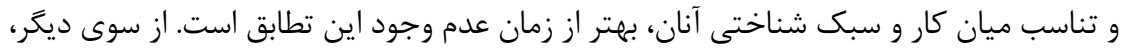

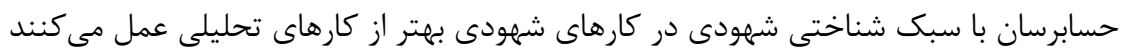

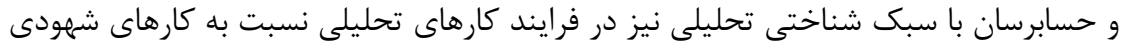

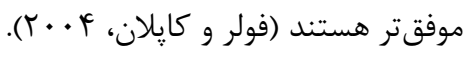

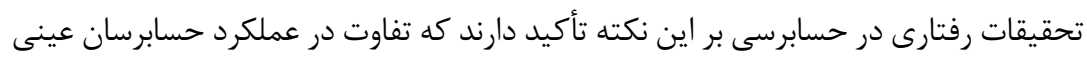

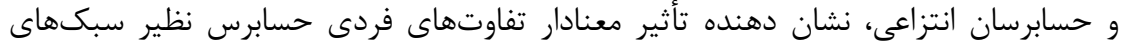

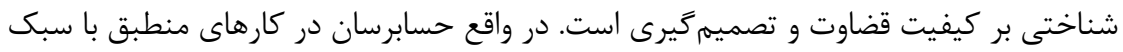

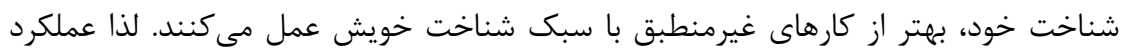

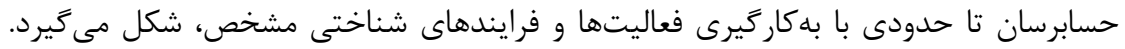

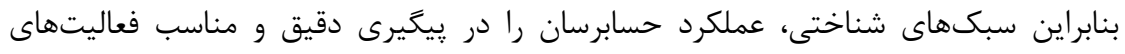

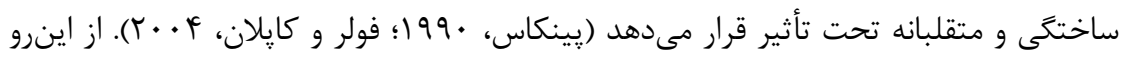

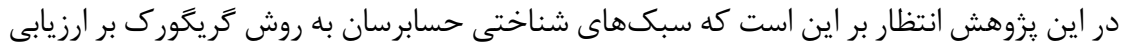

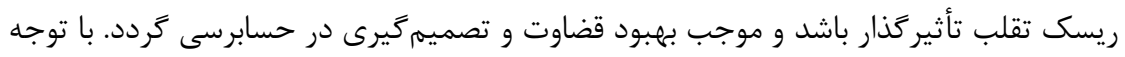

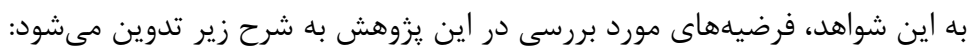
فرضيه اصلى: سبك هاى شناختى حسابرسان به روش تريكورك بر ارزيابى ريسك تقلب توسط ايشان تأثير مثبت و معنادارى دارد.

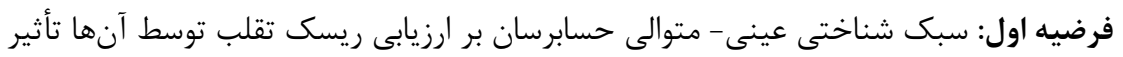
مثبت و معنادارى دارد. فرضيه دوم: سبك شناختى انتزاعى- متوالى حسابرسان بر ارزيابى ريسك تقلب توسط آنها تأثير مثبت و معنادارى دارد.

فرضيه سوم: سبك شناختى عينى- تصادفى حسابرسان بر ارزيابى ريسك تقلب توسط مارد آنس آنها تأثير مثبت و معنادارى دارد. فرضيه جهارم: سبك شناختى انتزاعى - تصادفى حسابرسان بر ارزيابى ريسك تقلب تودئ توسط آنها تأثير مثبت و معنادارى دارد. با توجه به اهداف و فرضيههاى اين يزوهش، مدل مفهومى در شكل إدائ ارئه شده است. 


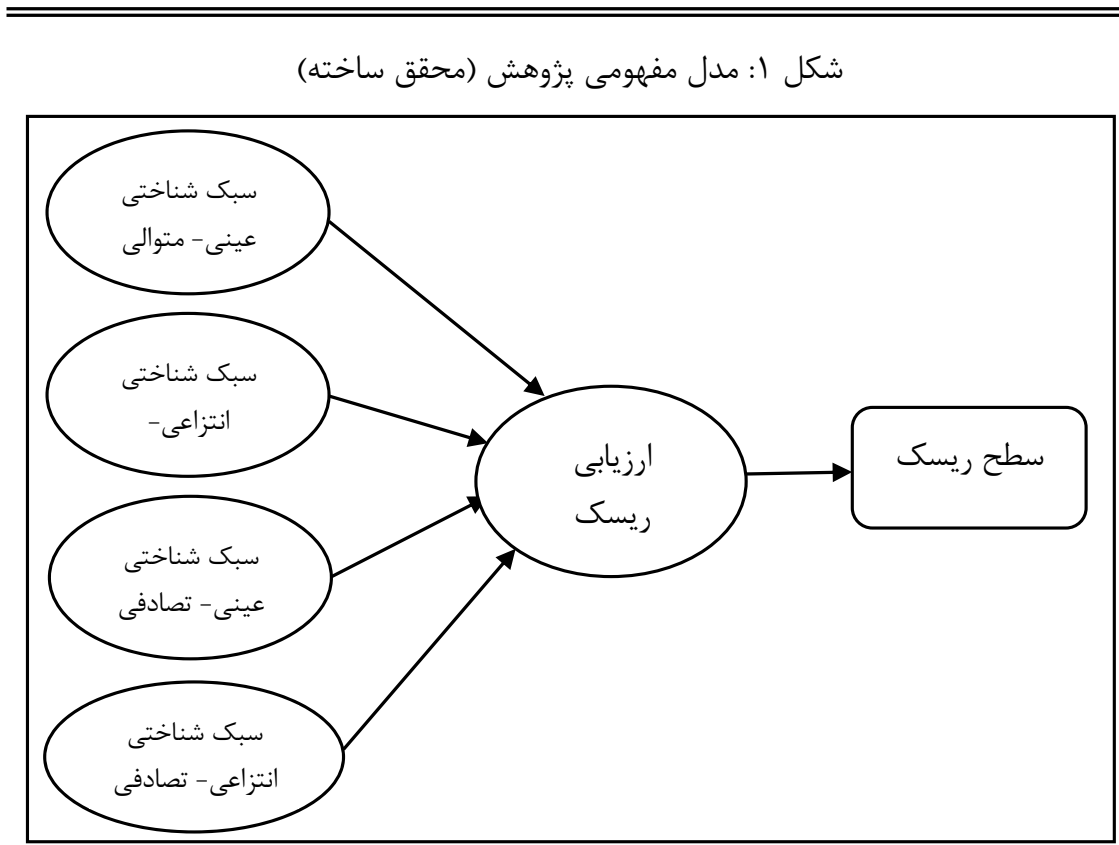

\section{F- روششناسى يزوهش}

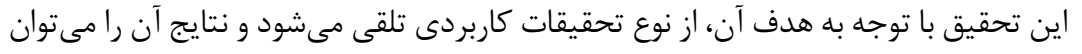

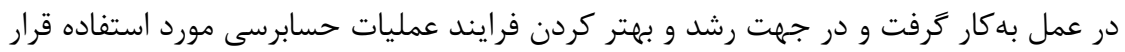

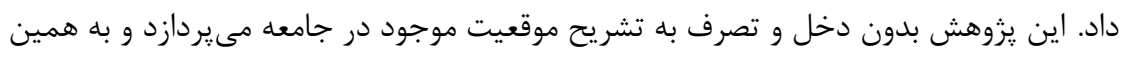

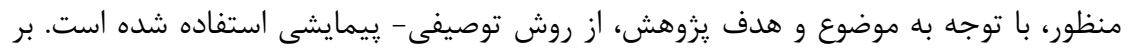

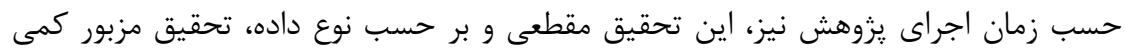

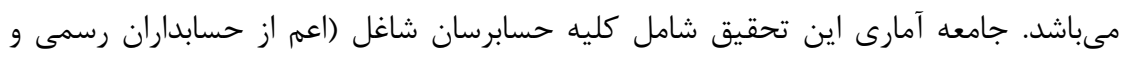

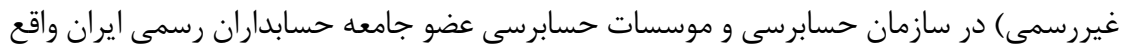

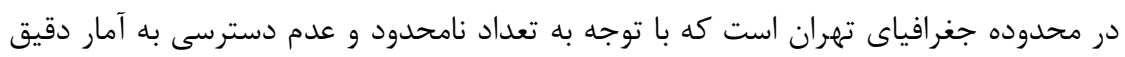
آنها، براى تعيين حجم نمونه از روش تعيين حجم نمونه در مدل يابى معادي كادلات ساختارى استفاده شده است.

به دليل آن كه روش مدل يابى معادلات ساختارى تا حدودى با برخى از جنبههاى ركرسيون

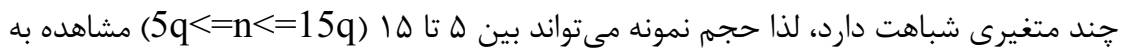

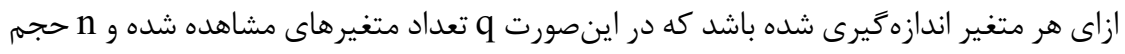

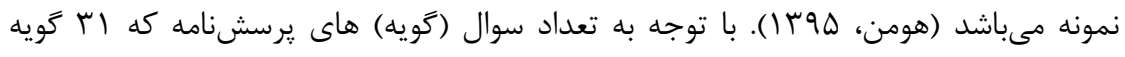




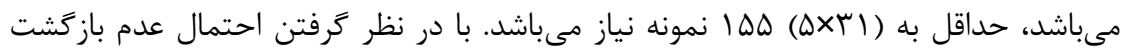

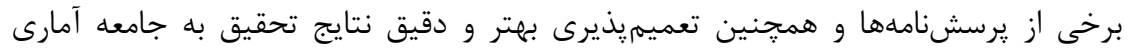

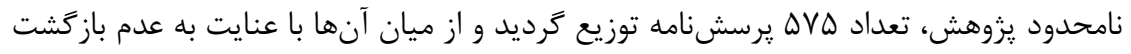

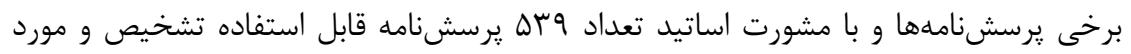

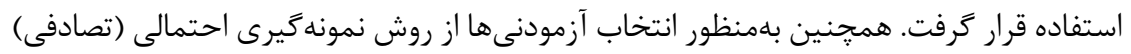
ساده در دسترس استفاده شده است.

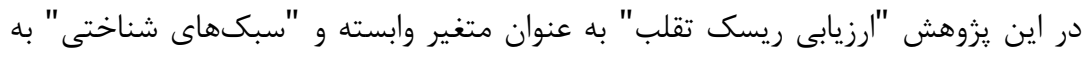

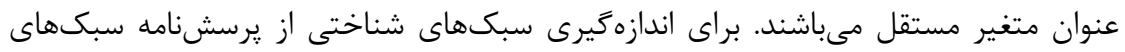

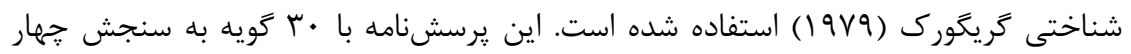

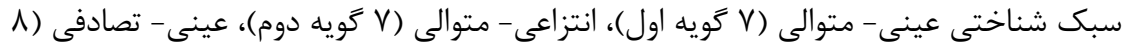

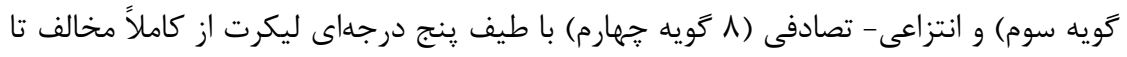
كاملاً موافق مى سيردازد.

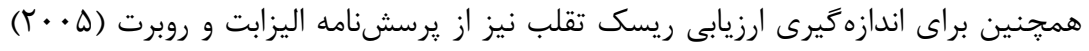

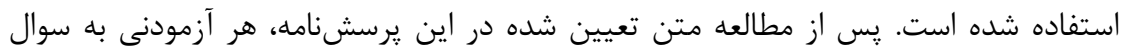

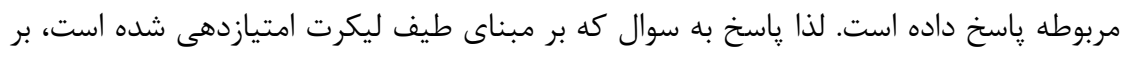

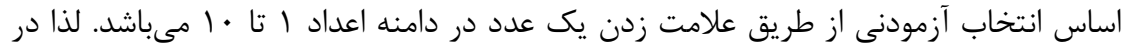

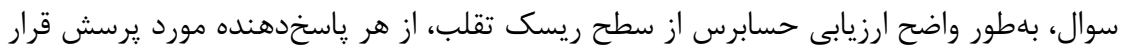

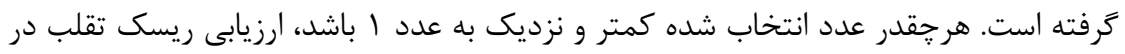

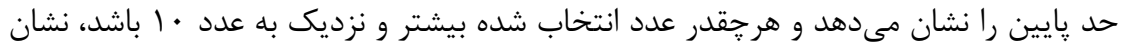

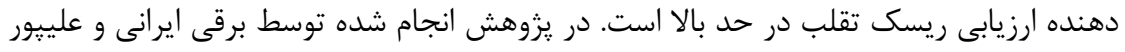

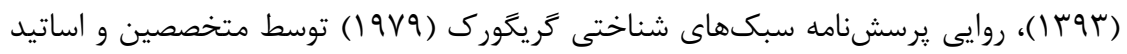

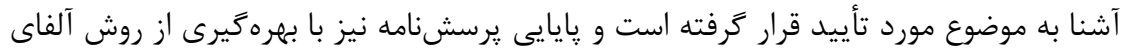

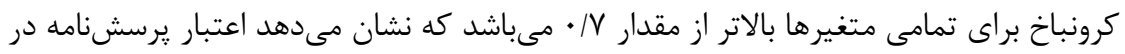

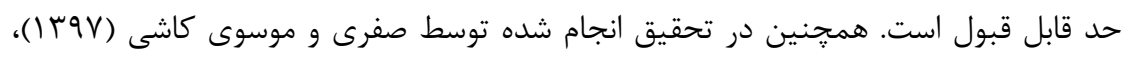

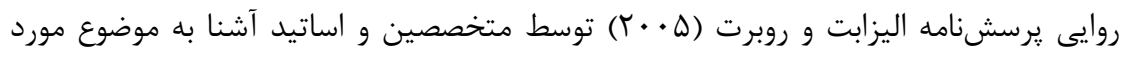

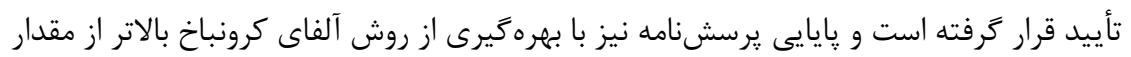

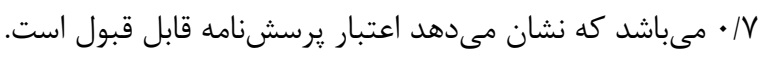

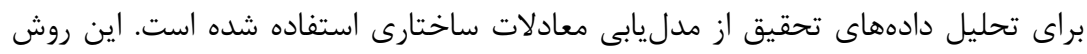

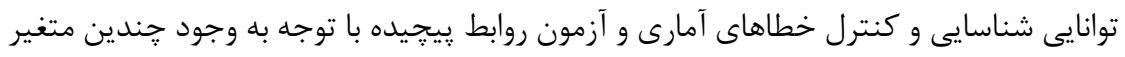

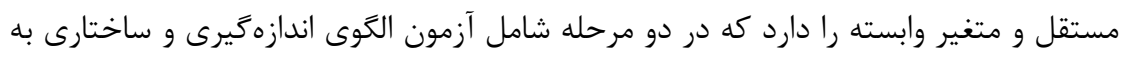


آزمون الكو مى يردازد كه الكوى اندازهخيرى اعتبار و روايى ابزارهاى اندازهخيرى را بررسى مى كند

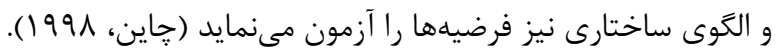

\begin{tabular}{|c|c|c|c|}
\hline منبع گَويهها & تعداد گويه- & عنوان متغير & تحقيق \\
\hline \multirow{4}{*}{ سبكهاى شناختى كريخورى (19V9) } & V & سبكى شناختى & \multirow{4}{*}{ مستقل } \\
\hline & V & سبك شناختى & \\
\hline & $\wedge$ & سبنى شناختى & \\
\hline & $\wedge$ & سبكى شناختى & \\
\hline 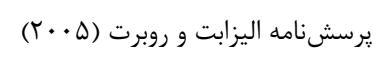 & 1 & ارزيابى ريسك تقلب & وابسته \\
\hline
\end{tabular}

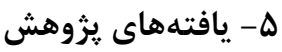

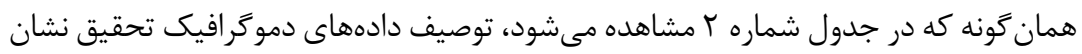

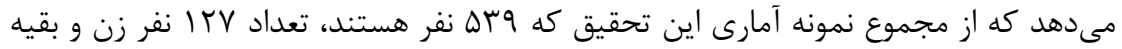

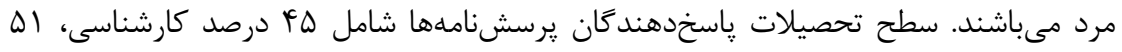

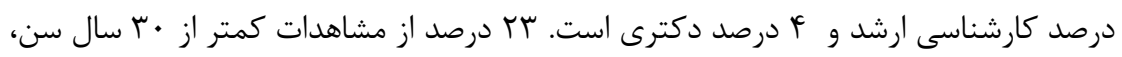

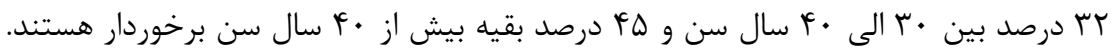

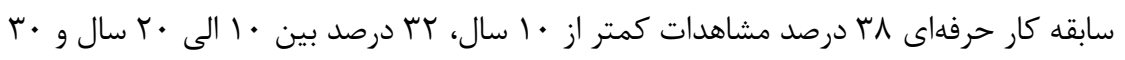

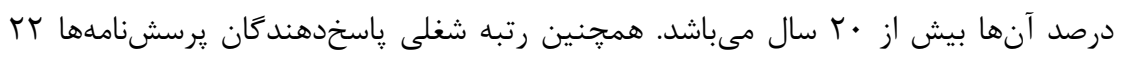

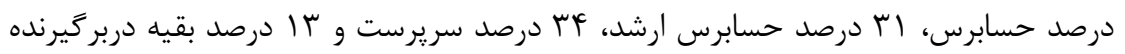

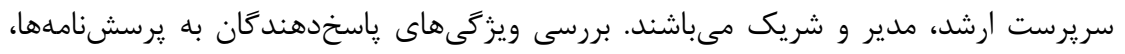

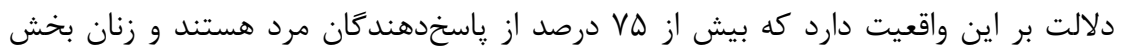

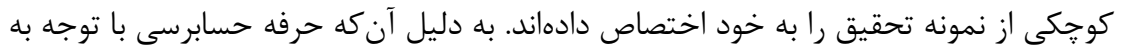

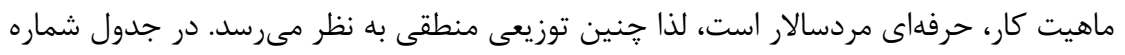

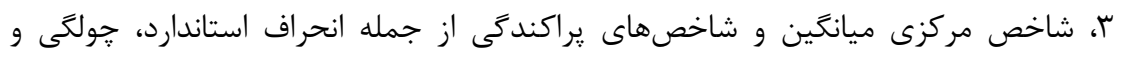

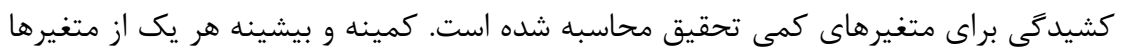




\begin{tabular}{|c|c|c|c|}
\hline \multicolumn{4}{|c|}{ يان و همكاران، تأثير سبك هاى شناختى حسابرسان بر ارزيابى ريسك تقلب... } \\
\hline \multicolumn{4}{|c|}{ جدول ז: مشخصات دموگرافيك براى نمونه مورد بررسى } \\
\hline درصد & 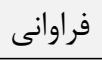 & 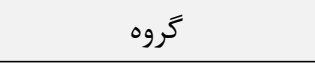 & متغير \\
\hline VG/FT & FIr & مرد & \multirow{2}{*}{ جنسيت } \\
\hline$r r / \Delta Q$ & ITV & 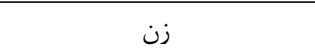 & \\
\hline$F F / A q$ & TET & كارشناسى & \multirow{3}{*}{ سطح تحصيلات } \\
\hline$\Delta \cdot / \Lambda r$ & TVE & كارشناسى ارشد & \\
\hline$F / T G$ & זr & دكترى & \\
\hline r & ITF & كمتر از •r سال & \multirow{3}{*}{ 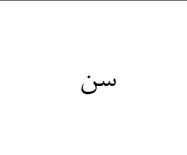 } \\
\hline ri/q1 & IVT & 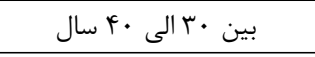 & \\
\hline $\mid \dot{Q} \Delta / \cdot \wedge$ & TET & بيش از · f سال & \\
\hline $\boldsymbol{\mu} \Lambda / \varphi$. & $r \cdot V$ & كمتر از • ا سال & \multirow{3}{*}{ سابقه كار حرفهاى } \\
\hline TI/VT & $|V|$ & بين •الى • ب سال & \\
\hline rq/AV & $\mid 91$ & 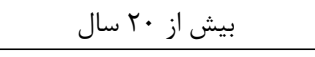 & \\
\hline$r T / \cdot V$ & 119 & 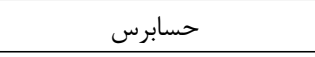 & \multirow{4}{*}{ ر به سازمانى } \\
\hline mI/19 & $19 \Lambda$ & حسابرس ارشد & \\
\hline 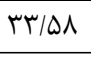 & 111 & سريرست & \\
\hline$I T / I V$ & vi & سريرست ارشد، مدير و شريك & \\
\hline $1 \cdots$ & $\Delta r q$ & \multicolumn{2}{|l|}{ جمع } \\
\hline
\end{tabular}

جدول rا: نتايج آمارى توصيفى براى متغيرهاى تحقيق

\begin{tabular}{|c|c|c|c|c|c|}
\hline كشيدَى & جولخى & انحراف انداف & ميانگين & مشاهداد & متغيرها \\
\hline$-\cdot / 11$ & $\cdot 1 \cdot r$ & $\cdot$ et & $r / \Delta \cdot$ & Drq & سبك شناختى عينى - متوالى \\
\hline$\cdot 1 \cdot \mathrm{f}$ & $-\cdot 111$ &.$/ 4 t$ & $r / \Delta \mid$ & $\Delta \mu q$ & سبك شناختى انتزاعى- متوالى \\
\hline$-\cdot / 4$ & $\cdot 1 \cdot 1$ & $\cdot / 19$ & $r / \Delta \cdot$ & $\Delta \mu q$ & سبك شناختى عينى - تصادفى \\
\hline$-\cdot 11 r$ & $-\cdot \cdot \cdot \Delta$ & $\cdot / 4$ & $r / D \mid$ & Drq & سبك شناختى انتزاعى- تصادفى \\
\hline$-\cdot|0|$ & $-\cdot / \cdot r$ & $r / \cdot F$ & $\Delta / \Delta V$ & $\Delta \mu q$ & ارزيابى ريسك تقلب \\
\hline
\end{tabular}

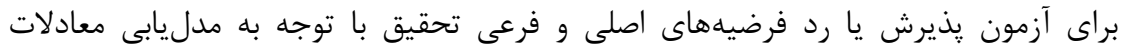

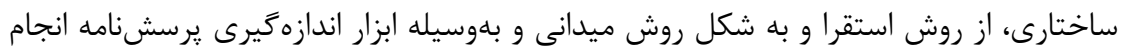

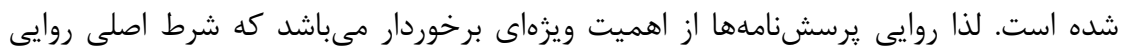

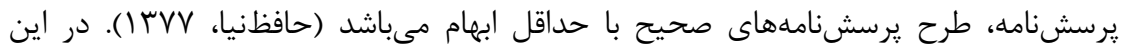


يروهش بهمنظور تعيين روايى يرسشنامهها از روايى محتوايى' و سازه׳ استفاده شد. در روايى

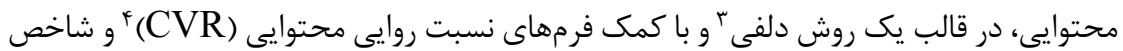

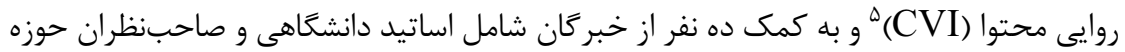

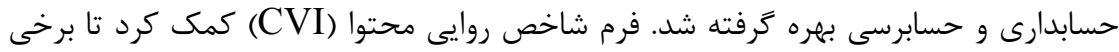

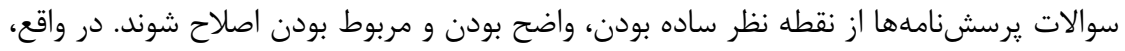

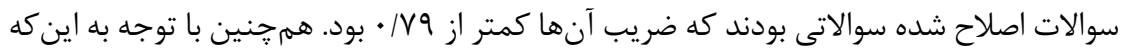

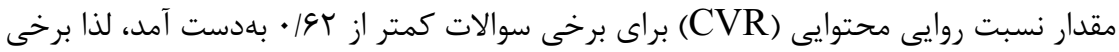

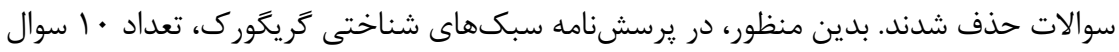

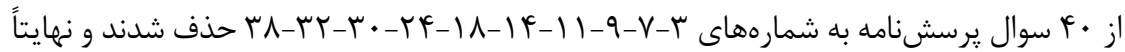

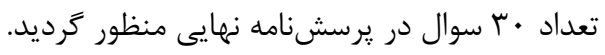

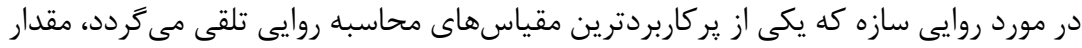

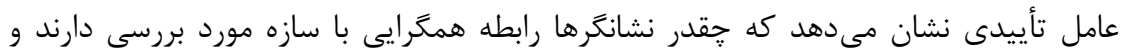

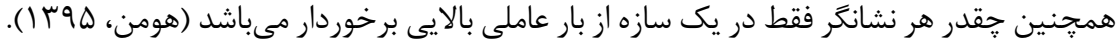

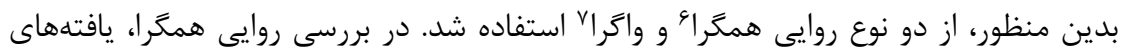

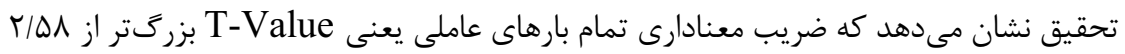
مىباشد. به عبارتى تمامى بارهاى عاملى با اطمينان 99 درصد معنادار است و مقادير تمام بارهاى

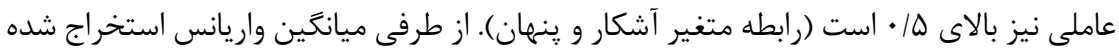

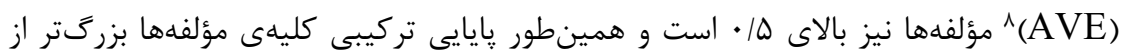

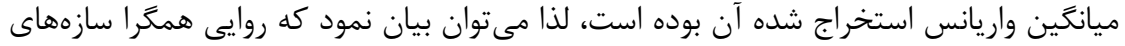

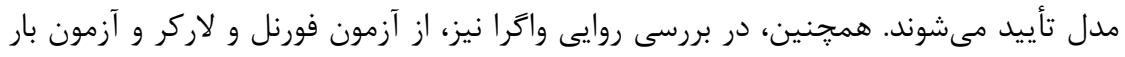

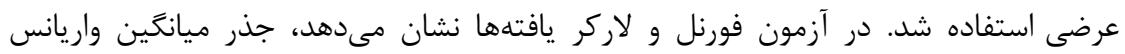
استخراج شده هر متغير ينهان بيشتر از حداكثر همبستخى آن متغير با ديكر متغيرهاى ينهان

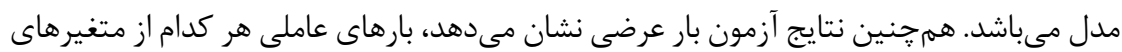

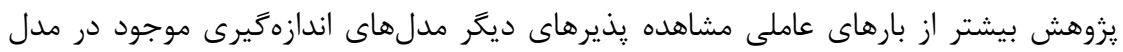

${ }^{1}$ Content Validity

${ }^{2}$ Construct Validity

${ }^{3}$ Delphi Method

${ }^{4}$ Content Validity Ratio

${ }^{5}$ Content Validity Index

${ }^{6}$ Convergent Validity

${ }^{7}$ Divergent Validity

${ }^{8}$ Average Variance Extracted 
مىباشد و از طرف ديكر، بار عاملى هر متغير مشاهدهيذير بر روى متغير ينهان متناظرش حداقل

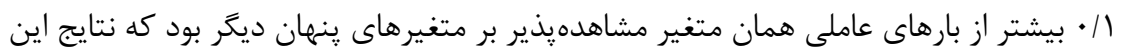

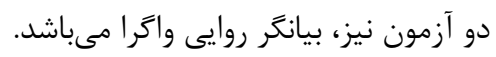

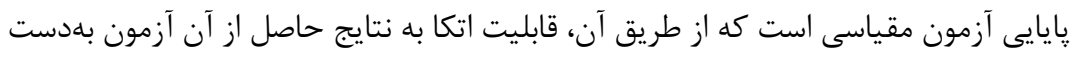

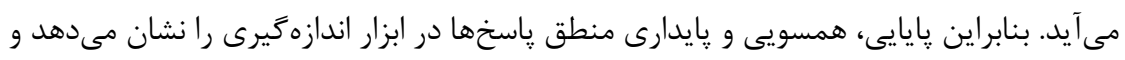

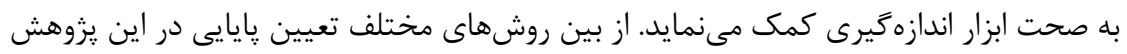

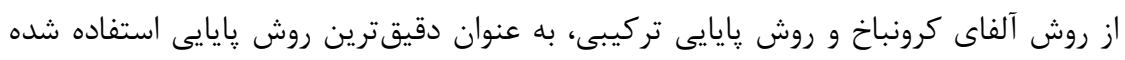

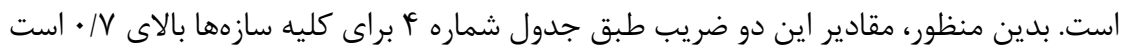

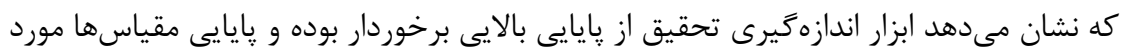

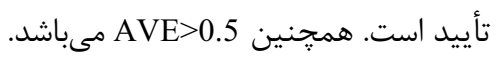
جدول fا: نتايج ضرايب روايى و يايايى خرده مقياسهاى يرسشنامهاى تحقيق

\begin{tabular}{|c|c|c|c|c|c|c|c|c|c|c|}
\hline$\Delta$ & f & $r$ & $r$ & 1 & ASV & MSV & AVE & CR & كرونباخ & عنوان مقياس \\
\hline- & - & - & - & $\cdot / V V$ & . T &.$/ 4 A$ &.$/ \Delta 9$ & - /AF & . /AT & عينى -متوالى \\
\hline - & - & - & $\cdot|\Lambda|$ & $\cdot / 4$. &.$/ 79$ & Trt & $.19 \Delta$ & . AT & $\cdot / \Lambda$ & انتزاعى -متوالى \\
\hline - & - & $\cdot / v 9$ & $\cdot|q|$ &.$/ F \Delta$ & $\cdot / / 1$ & Tr & . & $\cdot / v 9$ & $\cdot / \vee \wedge$ & عينى -تصادفى \\
\hline - & . $/ V F$ &.$/ r$. &.$/ 4 q$ &.$|q|$ & Tr & $\cdot / r \Delta$ & $\cdot \mid \Delta \Delta$ & . /AT & $\cdot / v 9$ & تصادفى \\
\hline$\cdot / V 8$ & $\cdot / r \Lambda$ & . & $\cdot / 48$ & . & $\cdot / 79$ & $\cdot|f|$ & $\cdot / \Delta V$ &.$/ 19$ & $\cdot / v 9$ & رزيابى ريسك \\
\hline
\end{tabular}

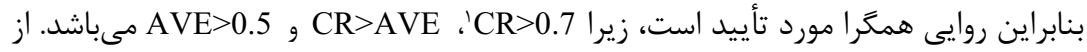

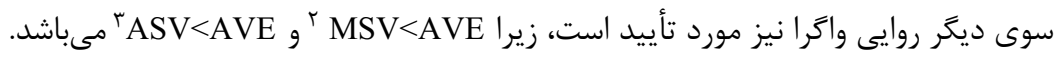

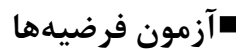

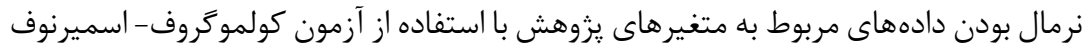

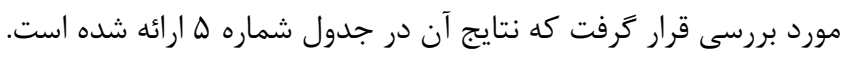

${ }^{1}$ Composite Reliability

${ }^{2}$ Maximum Shared Squared Variance

${ }^{3}$ Average Shared Squared Variance 
جدول ه: نتايج آمارى آزمون كولموَروف- اسميرنوف

\begin{tabular}{|c|c|c|c|}
\hline Sig. & آماره آزمون & تعداد مشاهده & متغيرها \\
\hline$\cdot 1999$ & $\cdot|\Delta T|$ & Qrq & سبك شناختى عينى - متوالى \\
\hline$\cdot 199$. &.$/ 4 I t$ & $\Delta r q$ & سبك شناختى انتزاعى- متوالى \\
\hline$\cdot \mid 4 \& \Lambda$ &.$/ 4 q 4$ & $\Delta r q$ & سبك شناختى عينى - تصادفى \\
\hline .1994 & ש & $\Delta r q$ & سبك شناختى انتزاعى - تصادفى \\
\hline$\cdot \mid 994$ & . & Q D & ارزيابى ريسك تقلب \\
\hline
\end{tabular}

همانطور كه در اطلاعات جدول شماره ه مشاهده مى شود، مقدار سطح معنادارى آماره آزمون

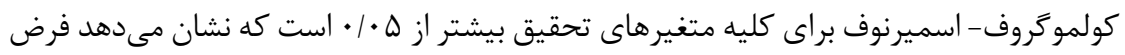

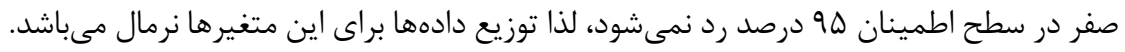

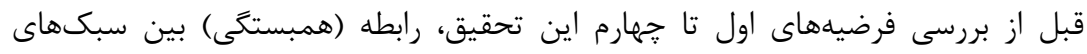

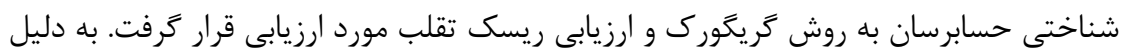

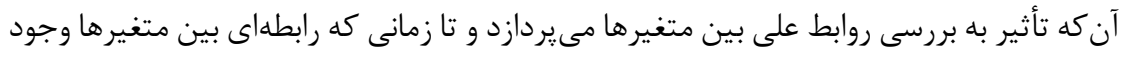

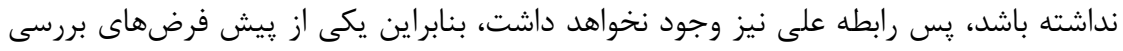

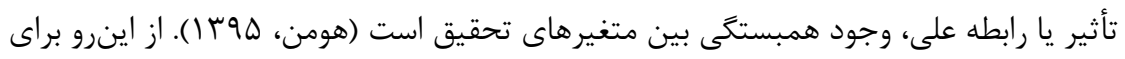

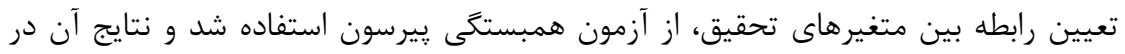

$$
\text { ماتريس زير ارائه شده است. }
$$

جدول 9: ماتريس همبستكى يِيرسون

\begin{tabular}{|c|c|c|c|c|c|}
\hline انتزاعى - تصادفى & عينى - تصادفى & انتزاعى - متوالى & عينى -متوالى & \multicolumn{2}{|c|}{ متغير } \\
\hline$* * \ldots / V \wedge \Delta$ & $* * / N M I$ & 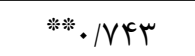 & *** & همبستكى & |رزيابى ريسك \\
\hline. & $\cdot \cdots \Delta$ & 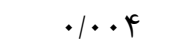 & $\cdot 1 \cdot \cdot \Delta$ & Sig. & تقلب \\
\hline
\end{tabular}

طبق اطلاعات مندرج در جدول شماره و، علامت *** نشاندهنده وجود همبستكى بين

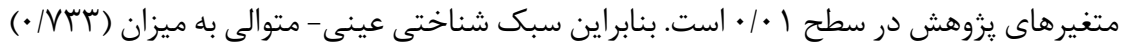

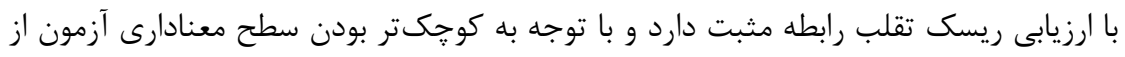

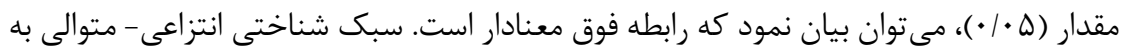

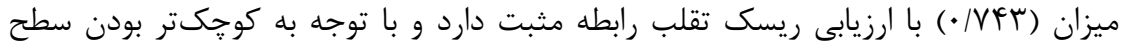

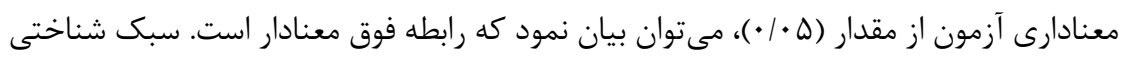

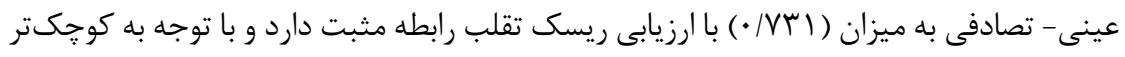


بودن سطح معنادارى آزمون از مقدار (ه •/•)، مىتوان بيان نمود كه رابطه فوق معنادار است.

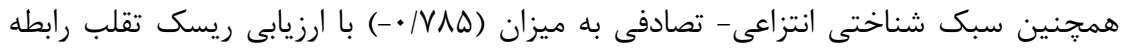

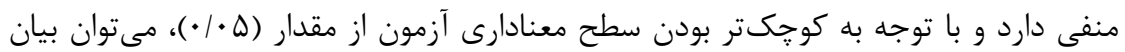
نمود كه رابطه فوق معنادار است.

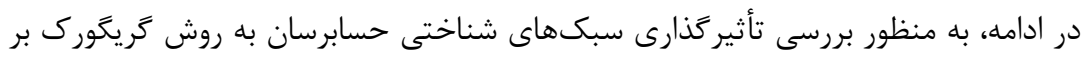
ارزيابى ريسك تقلب در يك مدل، از مدليابى معادلات ساختارى تأييدى استفاده شده است

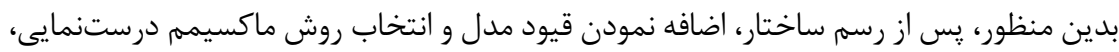

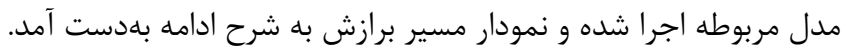

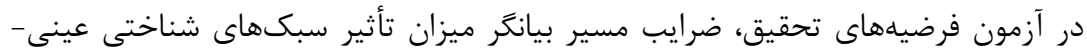

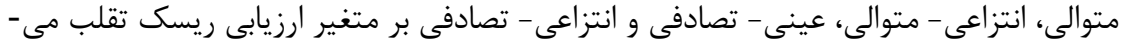

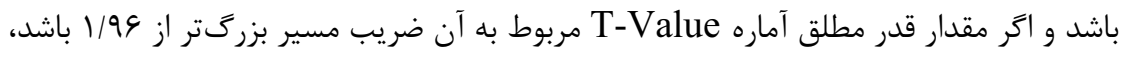

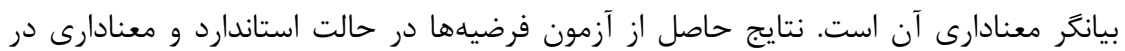

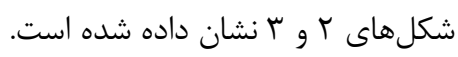

شكل r: نتايج آزمون فرضيه آنها در حالت استاندارد

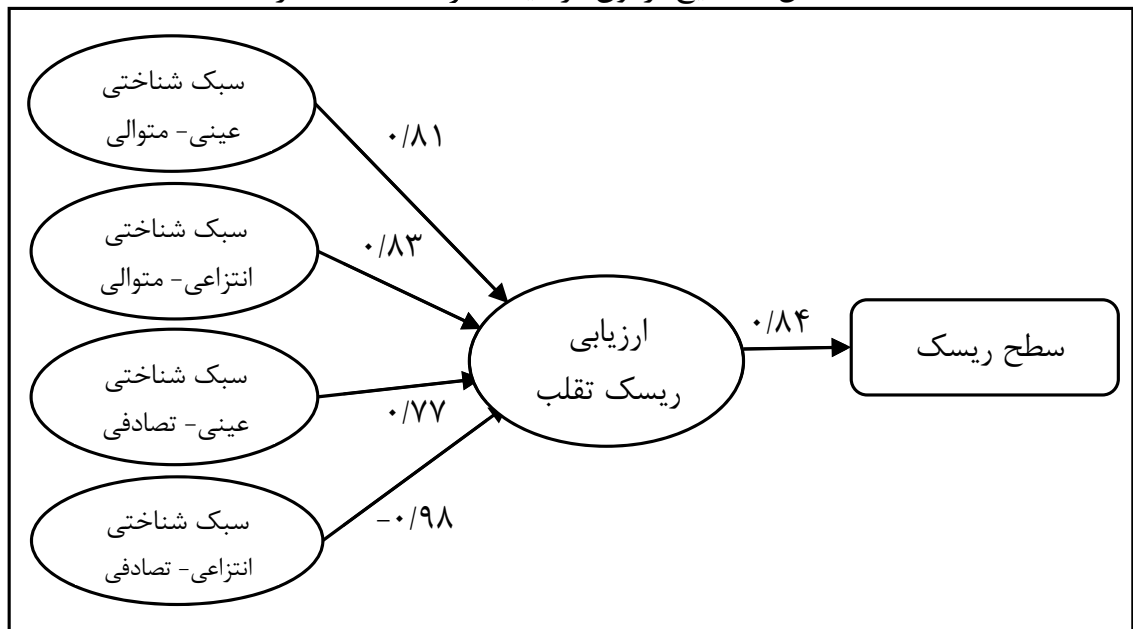

Chi-square $=1077 / 30, \mathrm{df}=454, \mathrm{p}-\mathrm{value}=0 / 05592, \mathrm{RMSEA}=0 / 061$

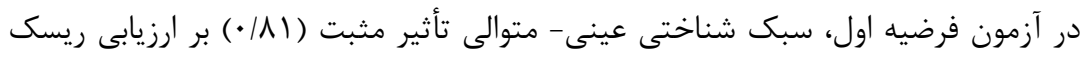

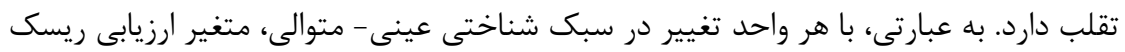

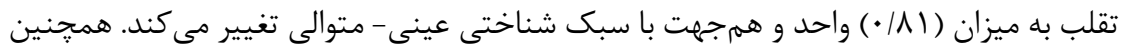

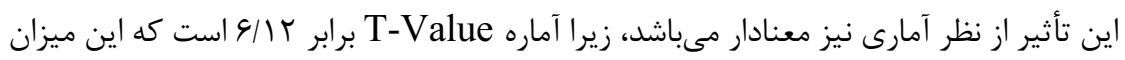


از مقدار 19 19 بيشتر مىباشد. بنابراين فرضيه اول كه مبين تأثير متغير سبك شناختى عينى -

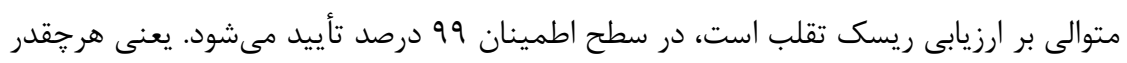

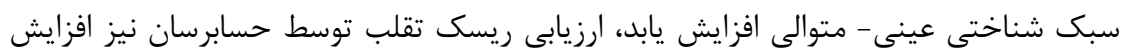

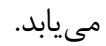

شكل rا: نتايج آزمون فرضيهها در حالت معنادارى

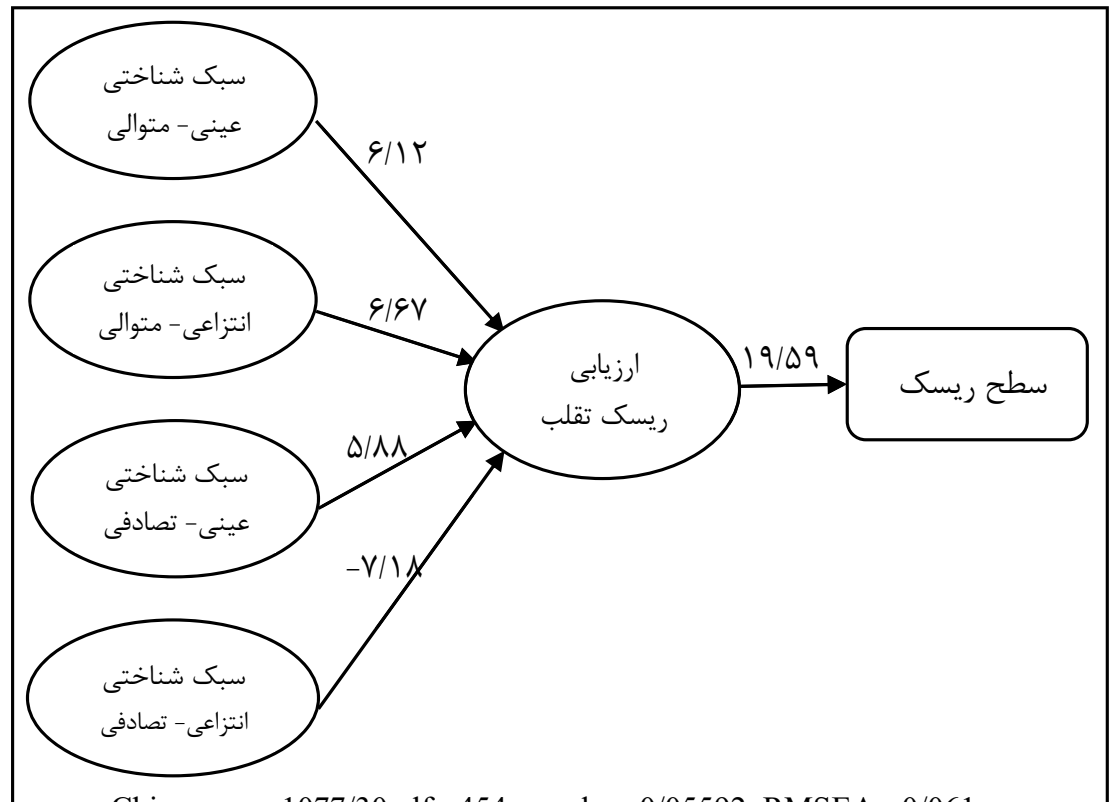

Chi-square $=1077 / 30, \mathrm{df}=454, \mathrm{p}$-value $=0 / 05592, \mathrm{RMSEA}=0 / 061$

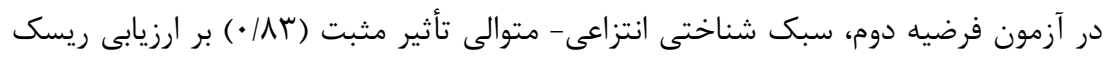

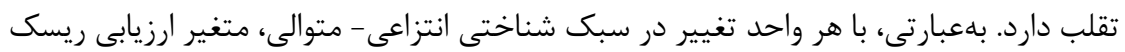

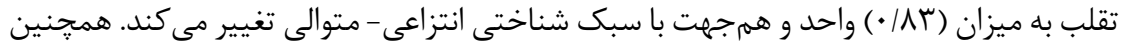

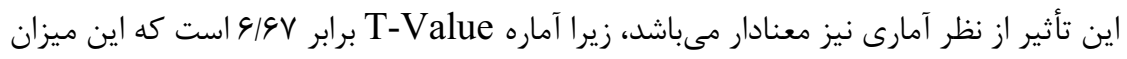

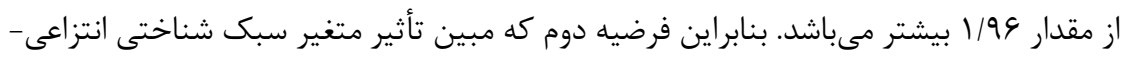

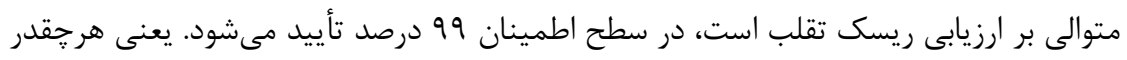

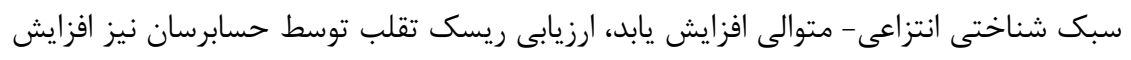

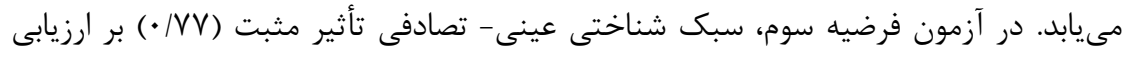

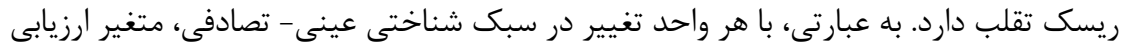

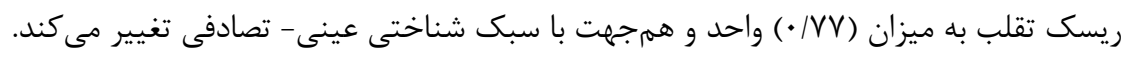




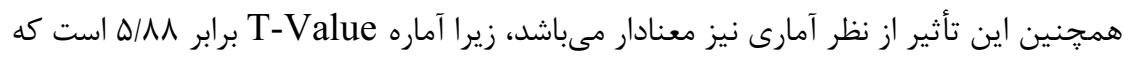

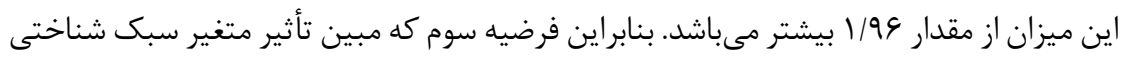

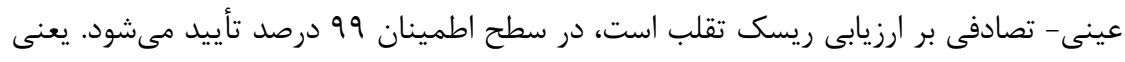

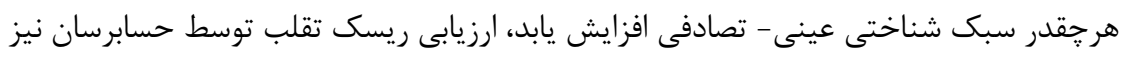

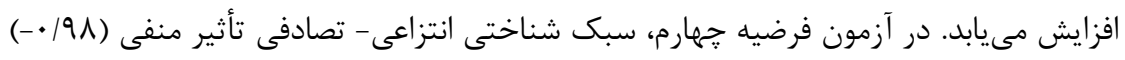

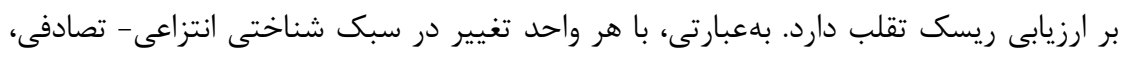

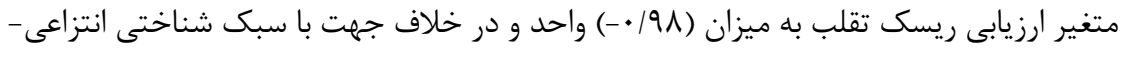

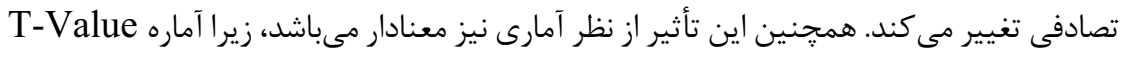

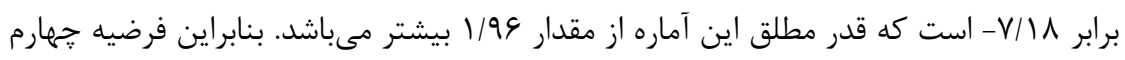

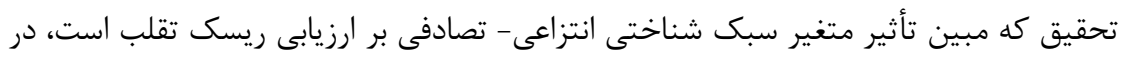

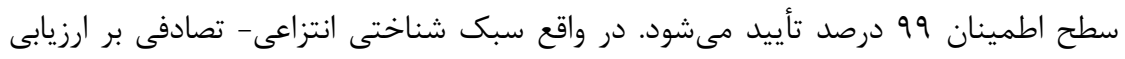

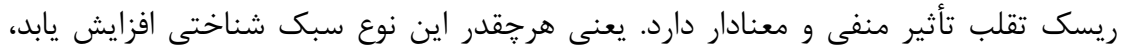

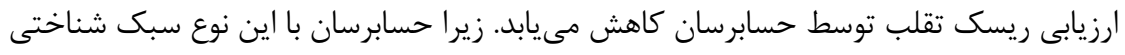

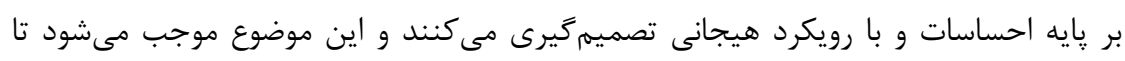
ارزيابى ريسك تقلب كاهش يابد.

\section{تأييد مدلها}

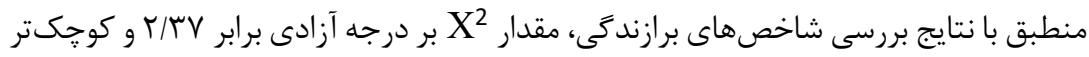

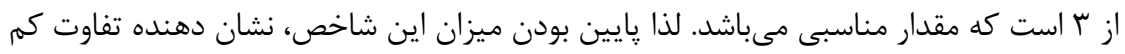

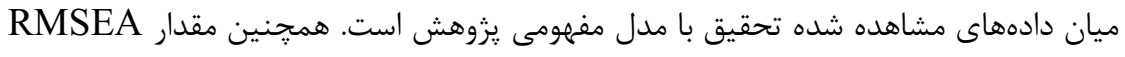

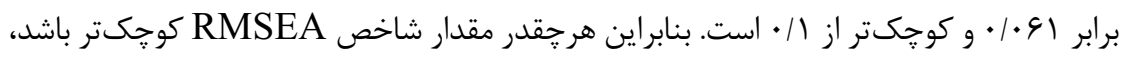

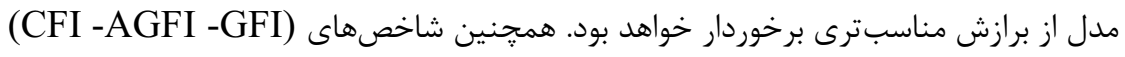

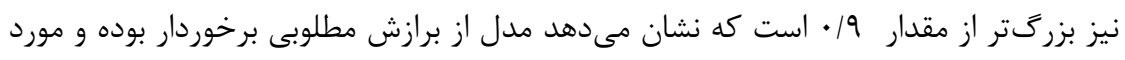

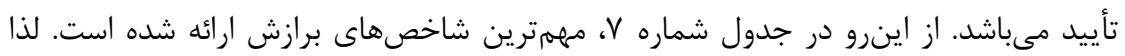

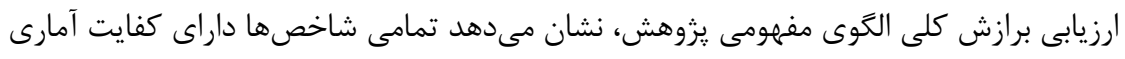

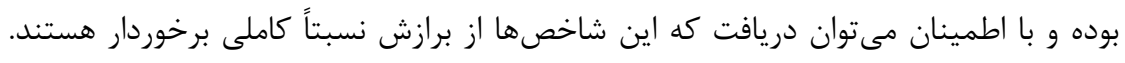

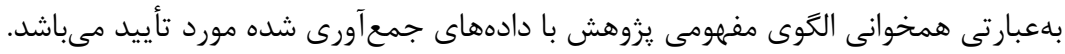


دو فصلنامه حسابدارى ارزشى و رفتارى، سال ينجم، شماره نهم، بهار و تابستان99"1

\begin{tabular}{|c|c|c|c|c|}
\hline \multicolumn{5}{|c|}{ جدول V: نتايج ارزيابى برازش كل الكوى مفهومى يثوهش } \\
\hline وضعيت برازش & برازش قابل قبول & مقاسير & اختصار & نام شاخص \\
\hline 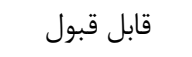 & - & l. VV/r. & - & سطح تحت يوشش (كاى اسكوئر) \\
\hline قابل قبول & 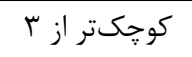 & $r / T V$ & $\mathrm{X}^{2} / \mathrm{df}$ & كاى اسكوئر بر درجه آزادى \\
\hline 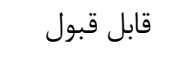 & 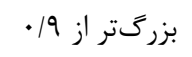 & .190 & GFI & شاخص نيكويى برازش \\
\hline 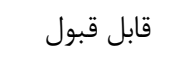 & 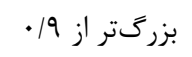 & .194 & AGFI & شاخص نيكويى برازش اصلاح شده \\
\hline قابل قبول & 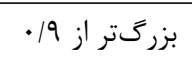 & .191 & CFI & شاخص برازش تطبيقى \\
\hline 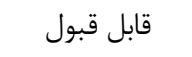 & 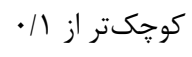 & $\cdot 1 \cdot 91$ & RMSEA & ريشه ميانگين مربعات خطاى برآورد \\
\hline
\end{tabular}

با توجه به جدول شماره مو نتايج بهدست آمده از ضرايب مسير و آماره t، وجود تأثير هر جهار سبك شناختى حسابرسان به روش گريخورك بر ارزيابى ريسك تقلب در سطح اطمينان 99 درصد تأييد مى به روش گريكورك بر ارزيابى ريسك تقلب تأثير دارند. لذا با توجه به ضراين نئ مسين مسير در در آزمون

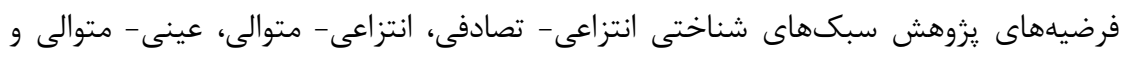
عينى - تصادفى به ترتيب بيشترين تأثير را بر روى متغير ارزيابى ريسك تقلب دارئ دارند.

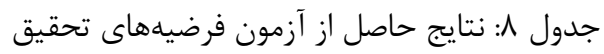

\begin{tabular}{|c|c|c|c|c|}
\hline نتيجه آزمون & $\begin{array}{c}\text { آماره } \\
\text { T }\end{array}$ & ضريب & عنوان فرضيهها & فرضيه \\
\hline تأييد مىشود & $9 / 1 T$ & $\cdot|\Lambda|$ & تأثير سبك شناختى عينى-متوالى بر ارزيابى ريسك تقلب & اول \\
\hline تأييد مىشود & $G \mid G V$ & • & تأثير سبك شناختى انتزاعى-متوالى بر ارزيابى ريسك تقلب & 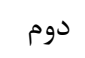 \\
\hline تأييد مىشود & $\Delta / \Lambda \Lambda$ & $\cdot / \mathrm{VV}$ & تأثير سبك شناختى عينى-تصادفى بر ارزيابى ريسك تقلب & سوم \\
\hline تأييد مىشود & $-V / 1 \Lambda$ & $-\cdot / 91$ & تأثيرسبك شناختى انتزاعى -تصادفى برارزيابى ريسك تقلب & جهارم \\
\hline
\end{tabular}

\section{9- بحث و نتيجه}

موضوع سبك شناختى افراد از اهميت مهمى برخوردار است، بهطورى كه جار جوب في فكرى افراد

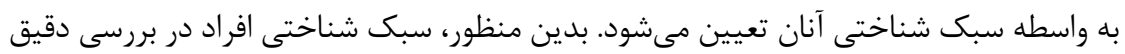

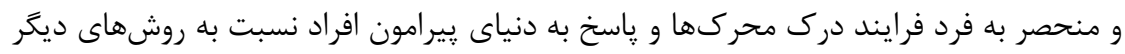
داراى اهميت است و به شكل انعطافيذير و مناسبتر در جهت ياسخ به نيازهاى اطلاعاتى 
اشخاص و تصميم گيرندًان با توجه به نحوه ادراك و يردازش اطلاعات توسط افراد و مدلهاى

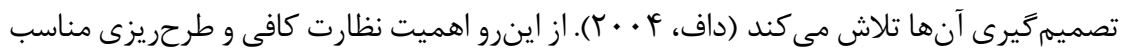

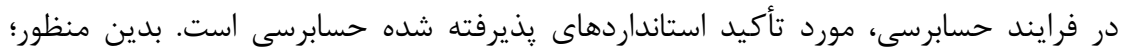

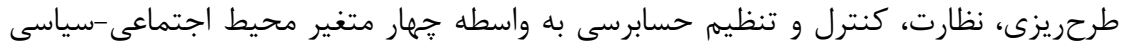

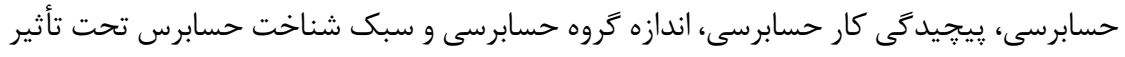

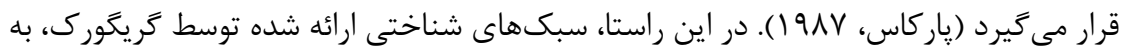

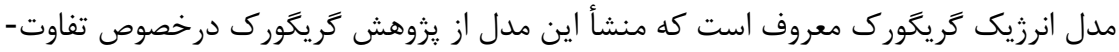

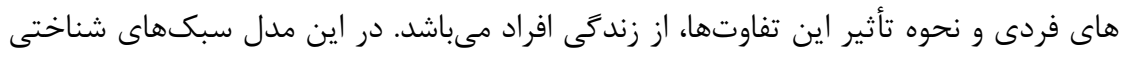

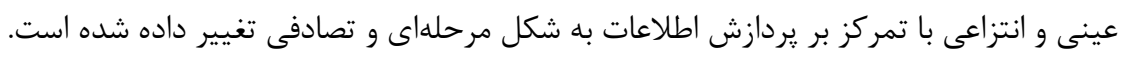

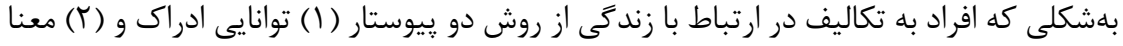

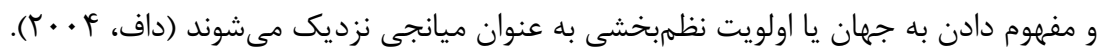

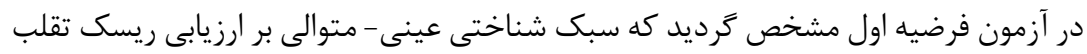

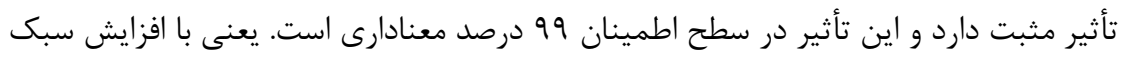

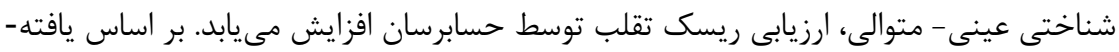

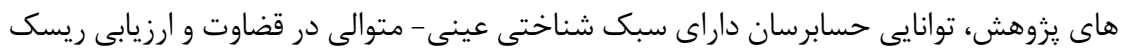

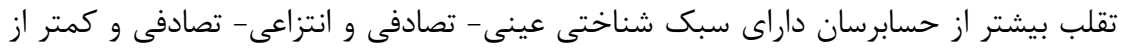

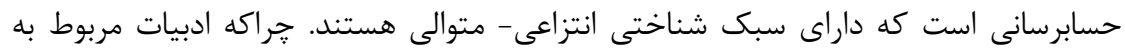

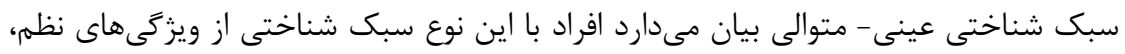
وقتشناسى و كمال

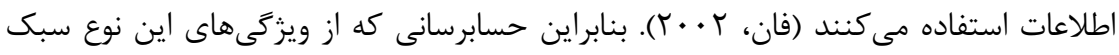

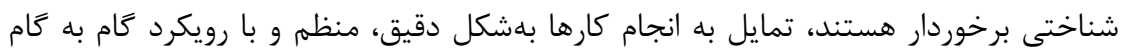

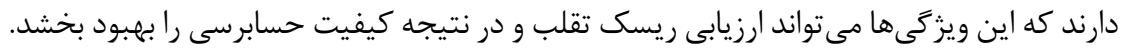

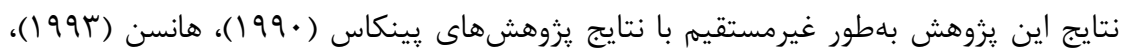

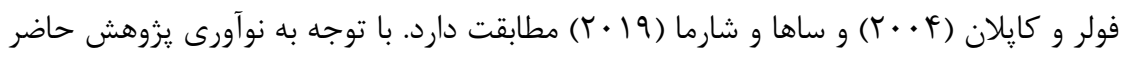
بهطور مستقيم يزوهش مشابهى كه در نتيجه جستجو در منابع مرتبط بود، وجود نداشت.

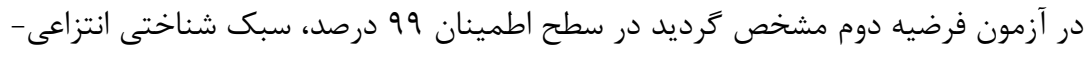

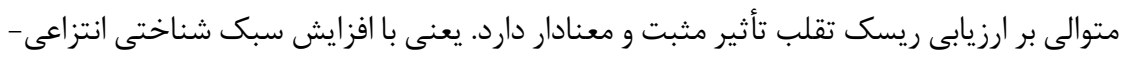

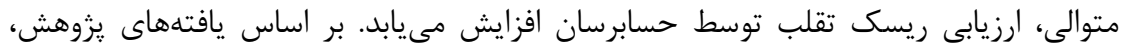

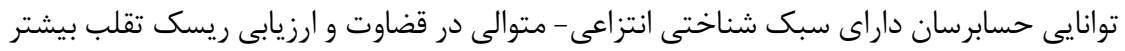

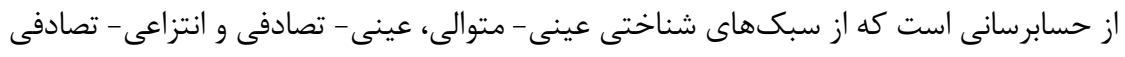


برخوردار مىباشند. جراكه ادبيات مربوط به سبك شناختى انتزاعى- متوالى بيان مى دارد افراد با

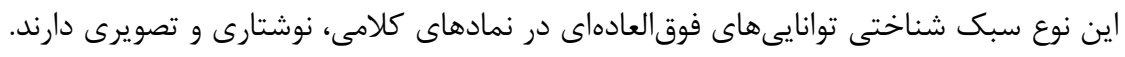

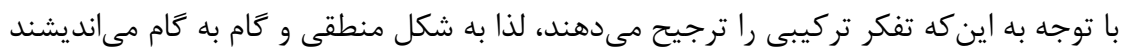

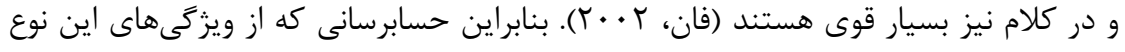

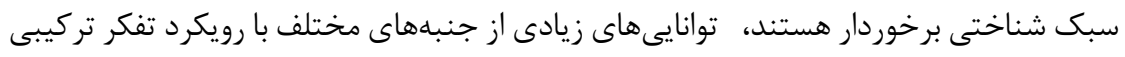

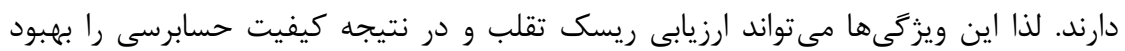

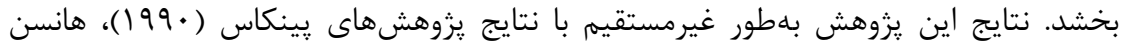

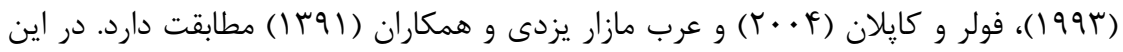

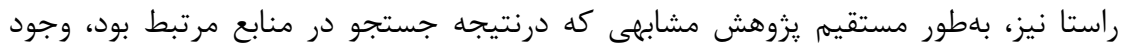

نتايج حاصل از آزمون فرضيه سوم بيانكر تأثير مثبت و معنادار سبك شناختى عينى - تصادفى دافي

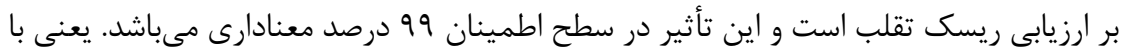
افزايش سبك شناختى عينى- تصادفى، ارزيابى ريسك تقلب توسط حسابرسان افزايش مى ديابد.

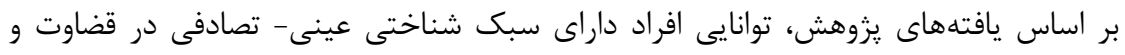

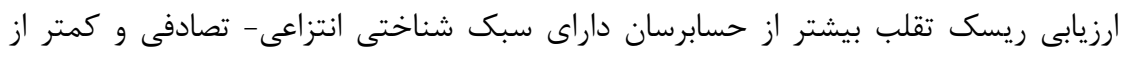

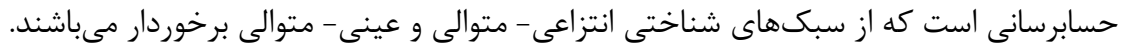

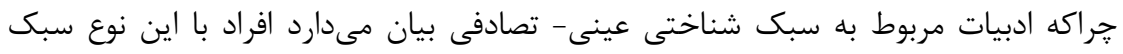

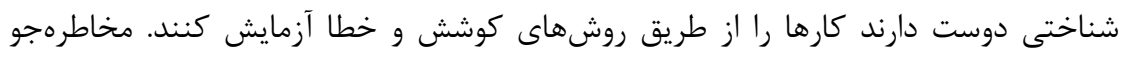

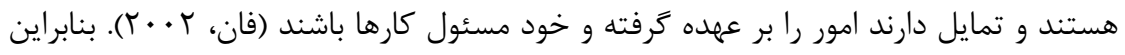

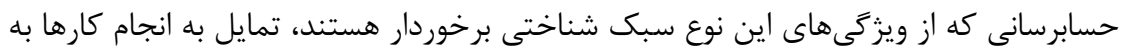

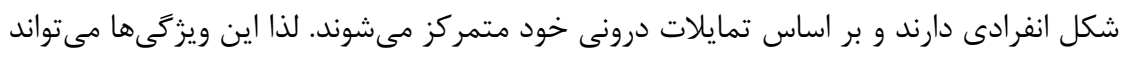

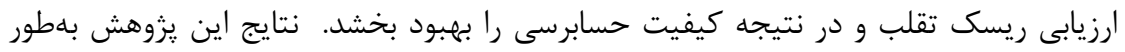

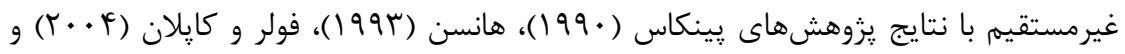

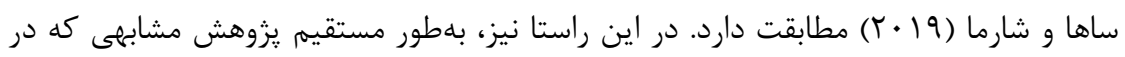
نتيجه جستجو در منابع مرتبط بود، وجود نداشت.

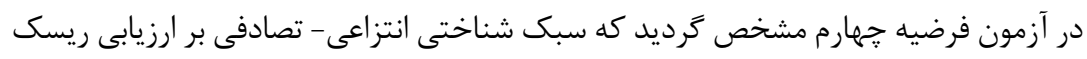

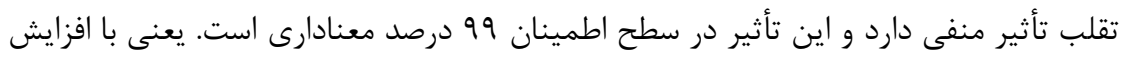

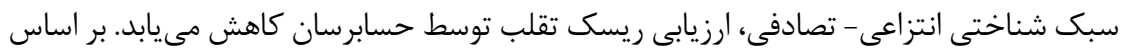

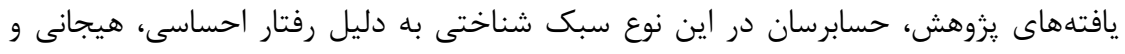

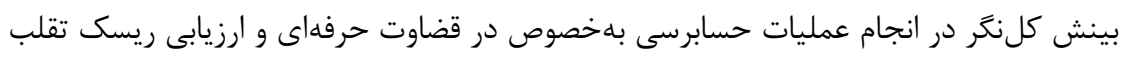


ضعيف عمل مى كنند. جراكه ادبيات مربوط به سبك شناختى انتزاعى- تصادفى بيان مىدارد

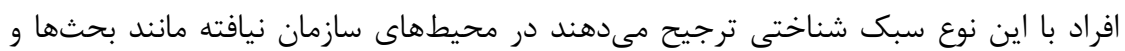

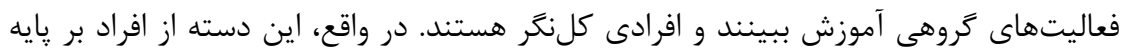

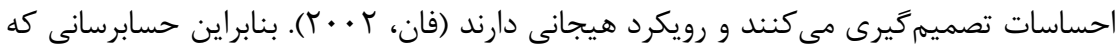

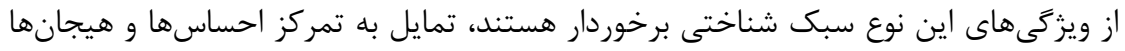

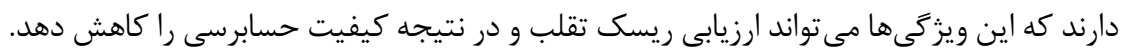

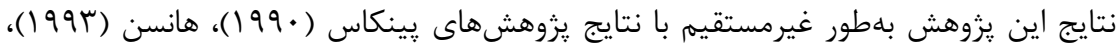

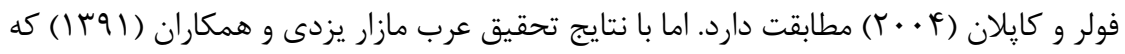

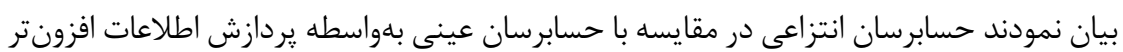

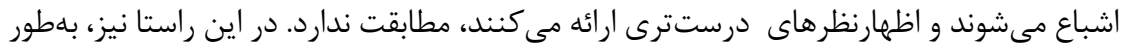

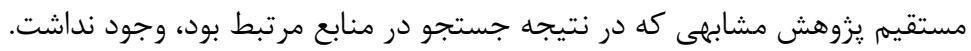

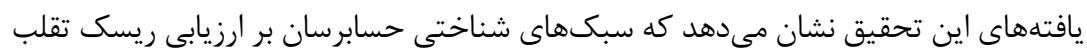

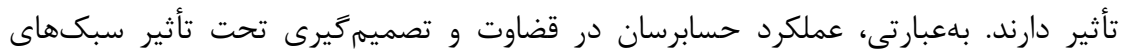

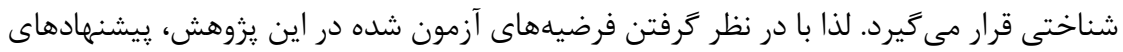
كاربردى اين تحقيق به شرح زير مىباشدي مطابق با نتايج اين يزوهش، سبك شناختى عينى - متوالى بر ارزيابى ريسك تقلب تأثياتير مثبت

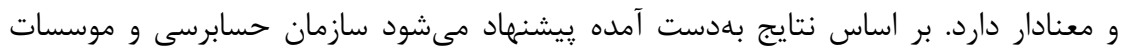

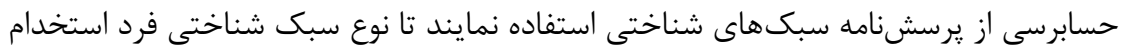

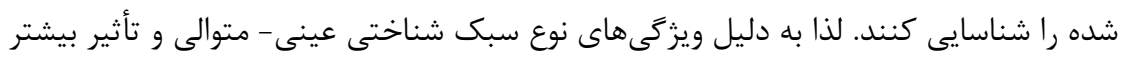
اين نوع سبك بر عملكرد حسابرسان در مقايسه با سبكهاى عينى - تصادفى و انتزاعى - تصادفى،

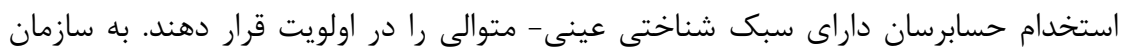

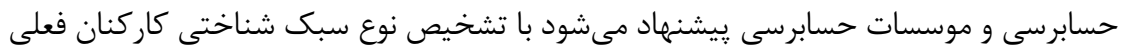

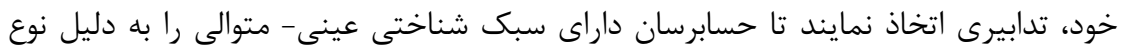

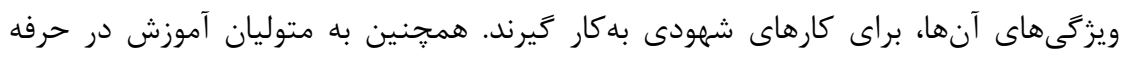

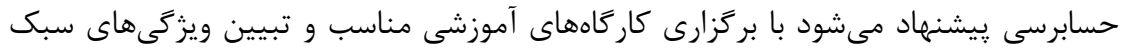

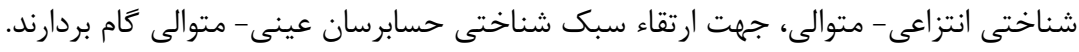

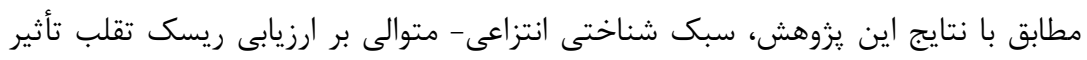

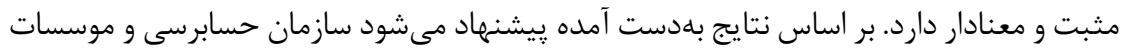

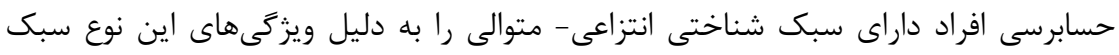

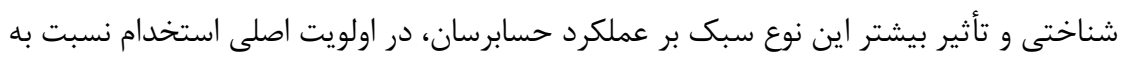


سبكهاى شناختى عينى- متوالى، عينى- تصادفى و انتزاعى- تصادفى قرار دهند. به سازمان

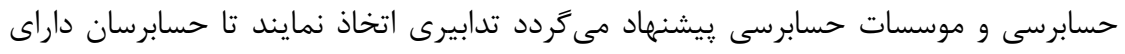

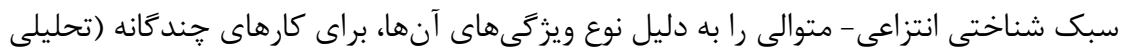

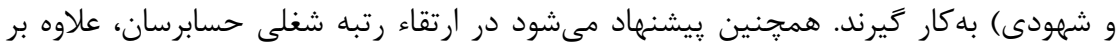

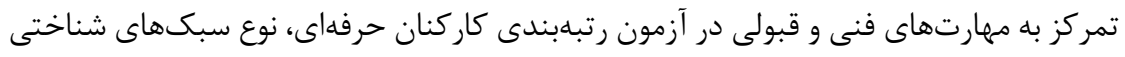

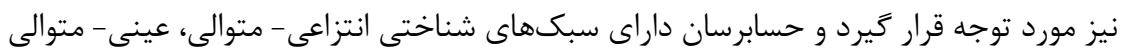

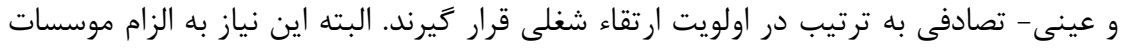

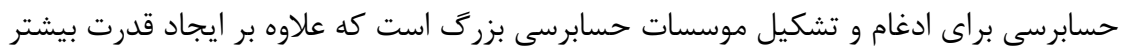

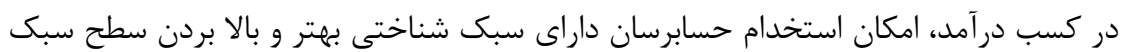
شناختى آنان را داشته باشند.

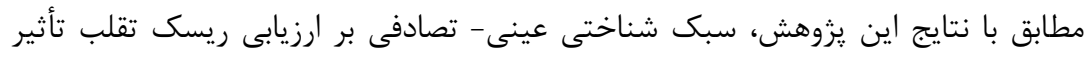

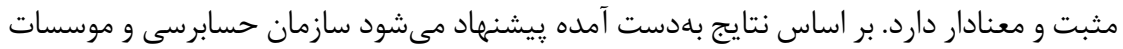
حسابرسى به دليل ويزگى هاى نوع سبك شناختى عينى - تصادفى و تأثير اين سبك بر عملكرد

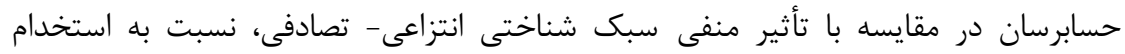

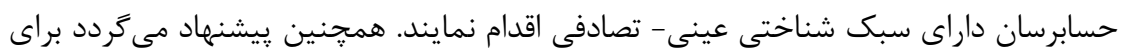

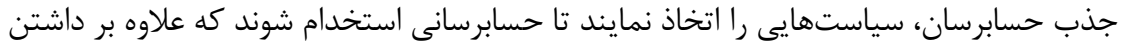
دانش، تخصص، تعهد و انكيزه لازم جهت فعاليت در حرفه حسابرسى، حداقل از ابعاد و مولفههاى

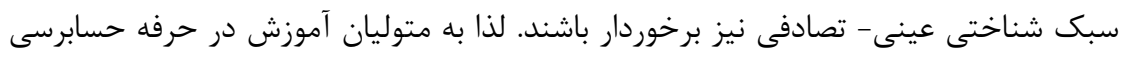

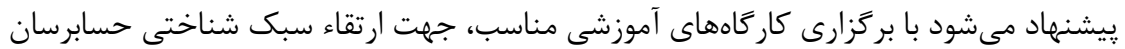
عينى - تصادفى كام بردارند. مطابق با نتايج اين يزوهش، سبك تردارند شناختى انتزاعى- تصادفى بر ارزيابى ريسك تقلب تأثير

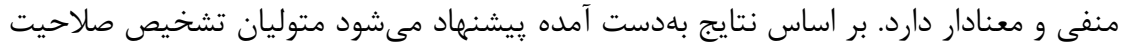

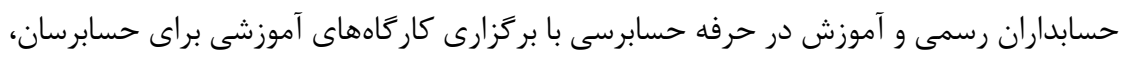

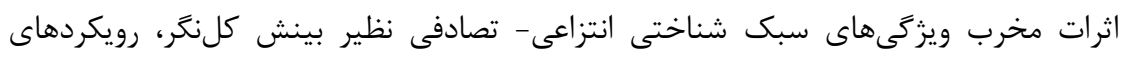
احساسى و هيجانى بر تصميمگيرى و قضاوت حرفهاى در حسابرسى راكوشزد نمايند. همجنين

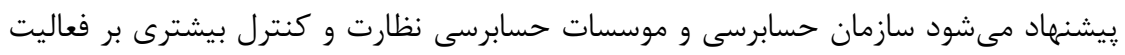

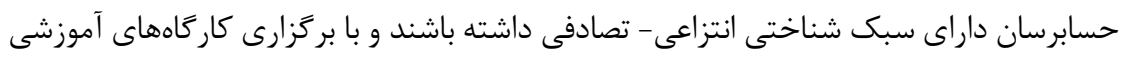
مناسب، اقدامات لازم جهت تقويت و ارتقاء سبك شناختى اين نوع حسابرسان را فأ فراهم نمايند.

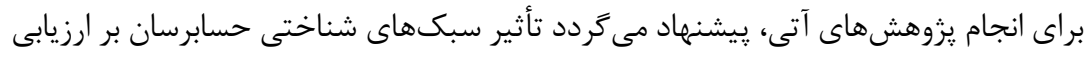

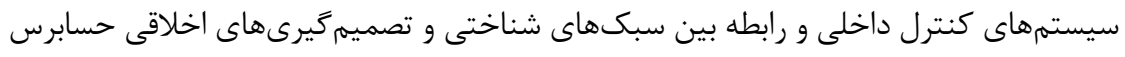



دكتر حميديان و همكاران، تأثير سبك هاى شناختى حسابرسان بر ارزيابى ريسك تقلب...

نيز مورد بررسى قرار كيرد. همجنين بيشنهاد مىشود تأثير ساير سبكهاى شناختى نيز بر مولفههاى مربوطه آزمون كردد. V- تقدير، تشكر و ملاحظه هاى اخلاقى نويسندكان اين مقاله از كليه عزيزانى كه با تكميل يرسشنامه، در انجام اين يزوهش مشاركت نموده اند، كمال تشكر و قدردانى را دارند. 1- يیوست ها الف: يرسشنامههاى يزوهش يرسشنامه سبكهاى شناختى گريكورى

\begin{tabular}{|c|c|c|c|c|c|c|}
\hline & & 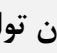 & ميزا & & & \\
\hline$\Delta$ & f & $r$ & $r$ & 1 & & \\
\hline 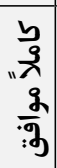 & $\frac{2}{: 3}$ & $\begin{array}{l}\text { :37 } \\
\text { y } \\
\frac{3}{2} \\
\end{array}$ & $\frac{9}{9}$ & $\begin{array}{l}y \\
\frac{3}{2} \\
1.3 \\
.3 \\
.3\end{array}$ & 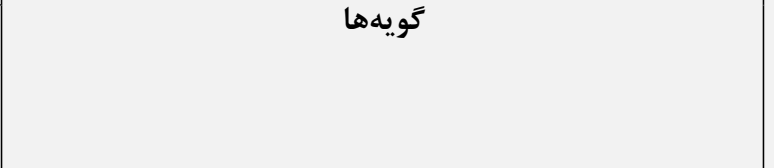 & .3 \\
\hline & & & & & ببه موقعيتهاى سازمان يافته نياز دارم و از آنها لذت مىبرم. & 1 \\
\hline & & & & & |دوست دارم در بروزمهاى علمى كار كنم. & t \\
\hline & & & & & |دستورالعمل هاى روشن و واضح را دوست دارم. & r \\
\hline & & & & & | آرام بنشى انجام دادن كارهاى سازنده هستم و نمى توانم براى مدت طولانى| & r \\
\hline & & & & & طبيعتاً شخصى سازمان دهنده هستم. & $\Delta$ \\
\hline & & & & & هميشه دستورالعملها را به طور كامل رعايت مى كنم. & 4 \\
\hline & & & & & |از اين كه خطايى را انجام دهم، نحَرانم. & $\vee$ \\
\hline & & & & & |براى فكر و كار، به محيط آرامى نياز دارم. & $\wedge$ \\
\hline & & & & & |دوست دارم درباره موضوعات بحث انكيز، ابراز نظر كنه. & 9 \\
\hline & & & & & |اطلاعات را جمع آورى و عقايد را تحليل مى كنم. & 1. \\
\hline & & & & & |تلاش مى كنم فردى روشن و عقلايى به نظر آيم. & 11 \\
\hline & & & & & سازمان يافته و منطقى فكر مى كنه. & $\pi$ \\
\hline
\end{tabular}


دو فصلنامه حسابدارى ارزشى و رفتارى، سال ينجم، شماره نهم، بهار و تابستان 9ج"1

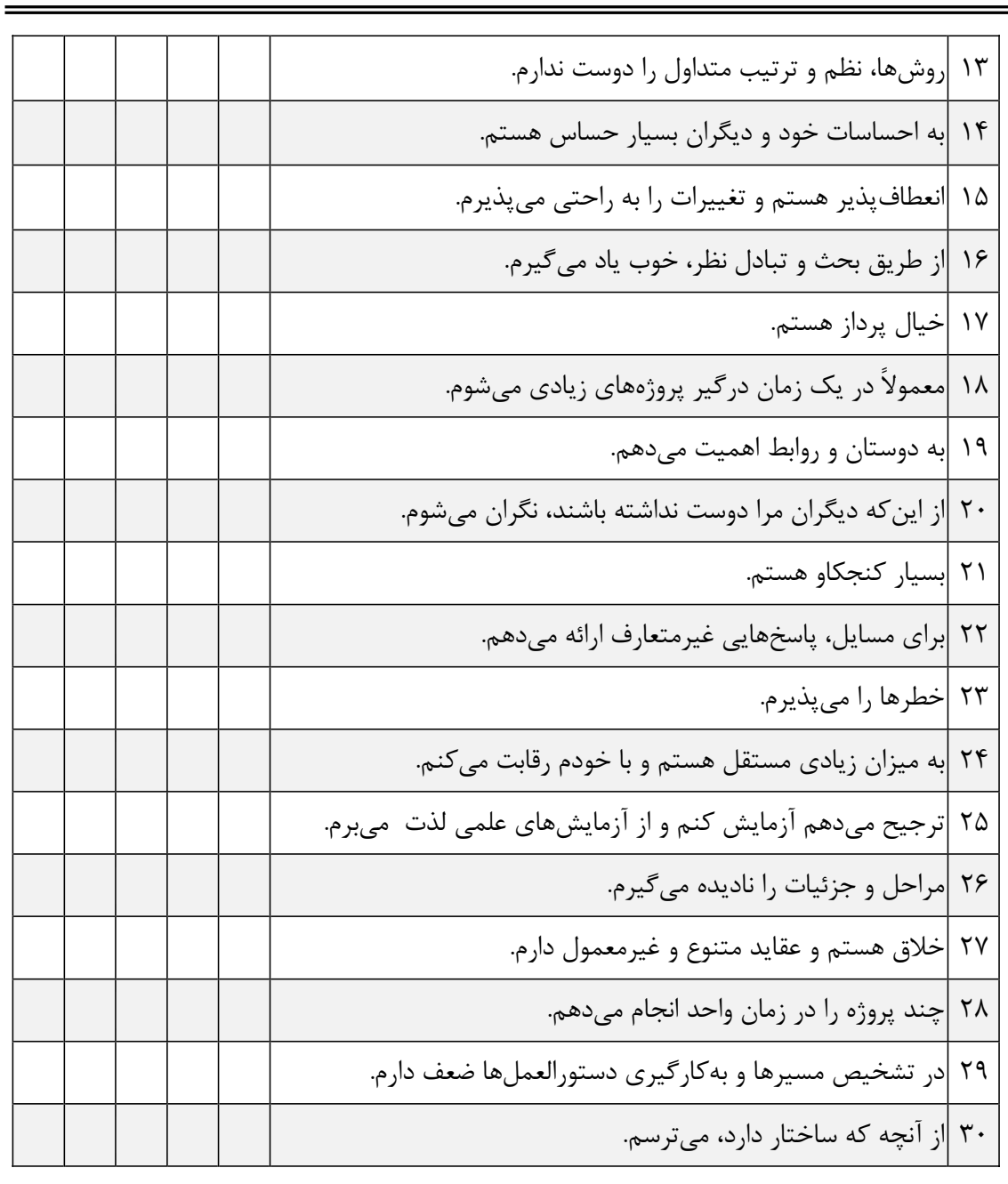

ب: برسشنامه ارزيابى ريسك تقلب

خواهشمند است بعد از مطالعه متن ذيل، به سوال مربوطه يّاسخ دهيد: فرض كنيد شما بهعنوان حسابرس مستقل شركت الف، مسئوليت حسابرسى آن را بر عهده داريد. بخشى از برنامه حسابرسى، درباره حسابهاى دريافتنى تجارى و مرتبط با تأييديه حساب-

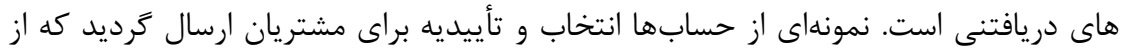
آنها درباره تأييد مقدار صحيح و بر گشت تأييديه سوال مى كند. اين رويه شواهدى مبنى بر اثبـ اثبات

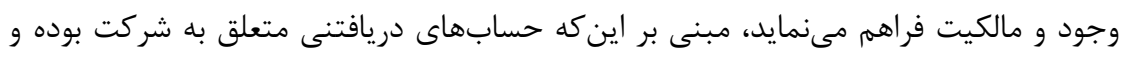


يورحيدرى، اميد؛ بذرافشان، سعيد. (1) (1). بررسى اثر ويزگى هاى فردى حسابرسان در تعيين

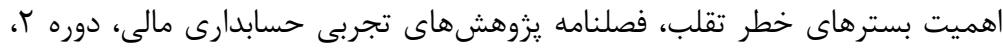

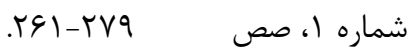

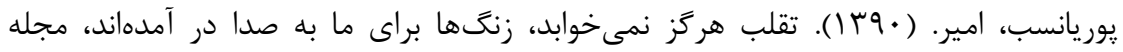

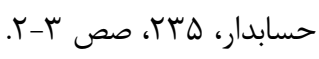

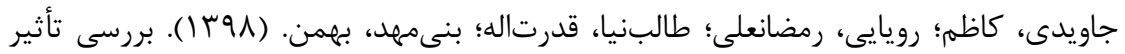
فاصله روانى (روانشناختى) بر قضاوت و تصميم گيرى در حسابدارى، فصلنامه حسابدارى

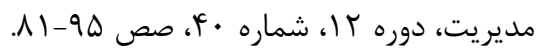

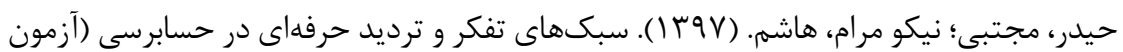
نظريه خود حكومتى ذهن)، دو فصلنامه حسابدارى ارزشى و رفتارى، دانشعاه خوارزمى، ماري،

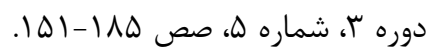

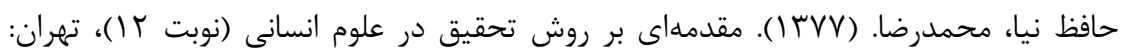

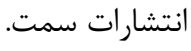

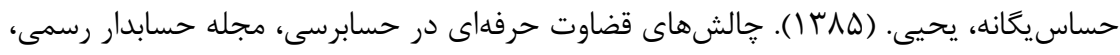

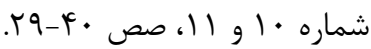

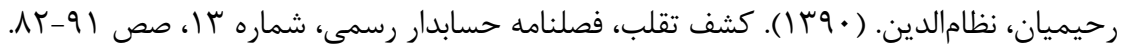

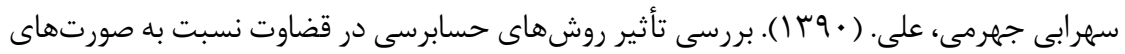

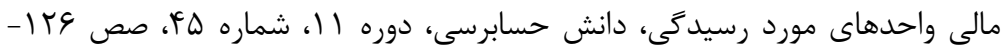

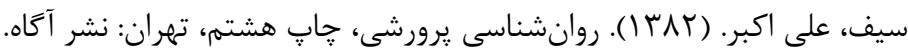

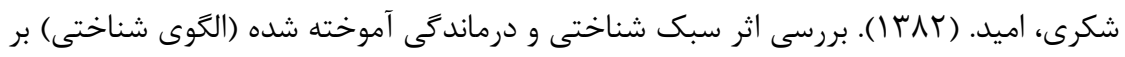

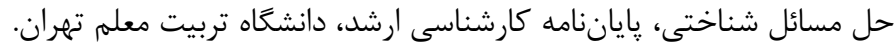

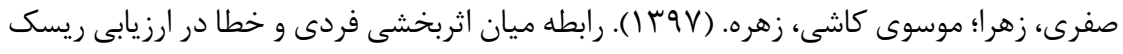

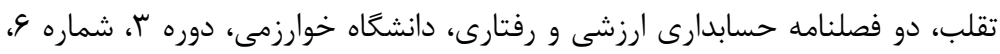
صص roD-rVV

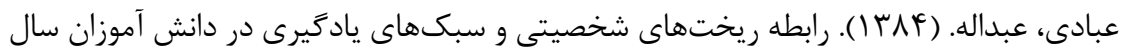

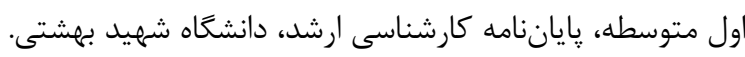

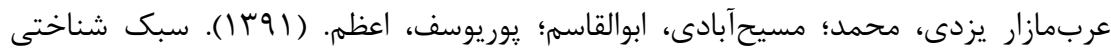
حسابرس، حجم اطلاعات و كيفيت اظهارنظر نسبت به تداوم فعاليت، فصلنامه بررسى - حسارئ

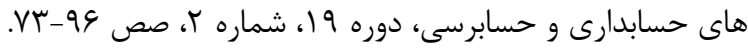




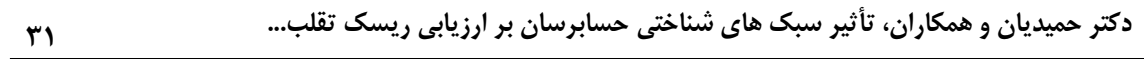

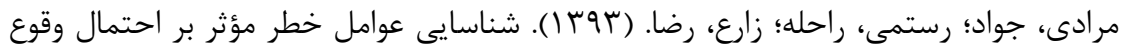

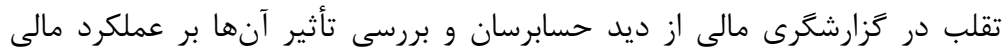

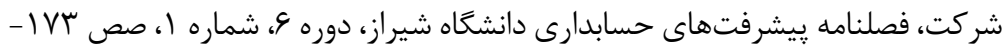

$$
\begin{aligned}
& .|f| \\
& \text { هومن، حيدر على. (ه9 (1). مدل يابى معادلات ساختارى با كاربرد نرم افزار ليزرل (با اصلاحات)، } \\
& \text { جإ هفتمه، تهران: انتشارات سمت. }
\end{aligned}
$$

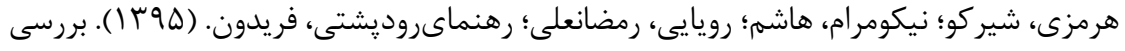

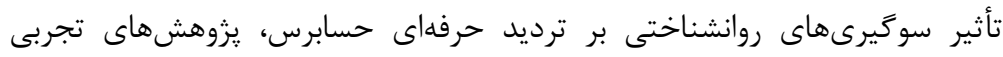

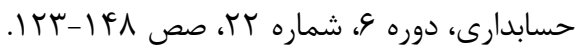

Abdelhakeem, A., K. H. Haj Haron, and T. A. Masron. 2017. Relationship between internal Shariah audit characteristics and its effectiveness. Humanomics 33 (2): 238-251.

Boyle, D. M., F. T. DeZoort, and D. R. Hermanson. 2015. The effect of alternative fraud model use on Auditors fraud risk judgments. Journal of Accounting and Public Policy 34 (6): 578-596.

Blazhenkova, O., and M. Kozhevnikov. 2008. The new object-spatialverbal cognitive style model: Theory and measurement. Applied cognitive psychology, Journal of Theoretical Psychology, 23 (5): 638-663.

Brasel, K. R., R. C. Hatfield, E. B. Nickell, and L. M. Parsons. 2019. The Effect of Fraud Risk Assessment Frequency and Fraud Inquiry Timing on Auditors Skeptical Judgments and Actions. Accounting Horizons 33 (1): 1-15.

Chin, w. w. 1998. Issues and opinion on structural equation modeling. MIS Quarterly 22 (1): vii-xvi.

Duff, A. 2004. The Role of Cognitive Learning Styles in Accounting Education: Developing Learning Competencies. Journal of Accounting Education 22 (1): 29-52.

Elizabeth, A. P., and J. R. Robert. 2005. fraud risk assessments and Auditors professional skepticism. Managerial Auditing Journal 20 (3): $321-330$.

Fuller, L. R., and S. E. Kaplan. 2004. A note about the effect of auditor cognitive style on task performance. Behavioral Research in Accounting 16: 131-143. 
Gregorc, A. F. 1979. Learning/Teaching styles: potent forces behind them. Scientific Research an Academic Publisher, in Educational Leadership 5: 234-237.

Grigorenko, E. L, and R. J. Sternberg. 1995. Thinking styles, International Handbook of Personality and Intelligence. New York, NY, US: Plenum Press 205-229.

Hopwood, W. S., J. J. Leiner, and G. R. Young. 2008. Forensic Accounting. Boston: McGraw-Hill/Irwin 3 (2): 109-136.

Hansen, J. D. 1993. The effect of information load and cognitive style on decision quality in a financial distress decision task. Dissertation for the Degree of Doctor of Philosophy, The University of Nebraska-Lincoln.

Jackson, C., and M. L. Jones. 1996. Explaining the overlap between personality and learning style. Personality and Individual Differences 20 (3): 293-300.

Knapp, C. A., and M. C. Knapp. 2001. The effects of experience and explicit fraud risk assessment in detecting fraud with analytical procedures. Accounting, Organizations, and Society 26 (1): 2537.

Kent, P., L. Munro, and T. Gambling. 2006. Psychological characteristics contributing to expertise in audit judgment. International Journal of Auditing 10 (2): 125-141.

Kolb, D. A. 2004. Experiential learning. www. learning Frame experience. com.

Messick, S. 1994. The matter of style: manifestations of personality in cognition. learning, and teaching, Educational Psychologist 29 (3): 121-136.

Pincus, K. V. 1990. Auditor individual differences and fairness of presentation judgments auditing. A Journal of practice \& Theory 9 (3): 150-166.

Phan, P. H. 2002. Technological Entrepreneurship, A Volume in Research in entrepreneurship and management. Lally School of Management and Technology Rensselaer Polytechnic institute. Printed in the United States of America.

Payne, E. A., and R. J. Ramsay. 2005. Fraud risk assessments and Auditors professional skepticism. Managerial Auditing Journal 20 (3): $321-330$. 


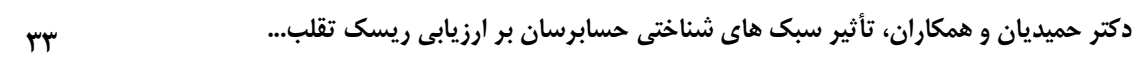

Pham, N. P. 2000. Learning styles. Retrieved January, 2010 from http://payson .tulan.edu/Pham/learning/lstyles.html.

Parkas, P. 1987. The Audit process as a function of the differentiated environment: an empirical study. Doctoral Dissertation, The Pennsylvania State University.

Rayner, S., and R. Riding. 1997. Towards a Categorization of Cognitive Styles and learning Styles. Educational Psychology 17 (1-2): 527.

Salarian, M., R. Ibrahim, and K. Nemati. 2012. The relationship between Users cognitive style and information seeking behavior among postgraduate engineering students. Procedia-Social and Behavioral Sciences 56 (8): 461-465.

Sternberg, R. J., and E. L. Grigorenko. 1997. Are Cognitive Style Still in Style? American Psychologist 52 (7): 700-712.

Saha, S., and R. R. K. Sharma. 2019. The impact of personality and cognitive style of managers on their work types. Journal of Management Development 38 (1): 58-71.

Schroder, H. M., M. J. Driver, and S. Streufert. 1976. Human Information Processing: Individuals and Groups Functioning in Complex Social Situations. New York: Holt. Rinehart and Winston Inc.

Verma, S. 1994. A study of thinking styles of tertiary students. Psycho-Lingua 31 (1): 15- 19.

Wells, J. T. 2005. Accountants need help fighting the war on frau. ACFE Association of Certified Fraud Examiners, ACFE founder urges anti-fraud education.

Woolfolk, A. E. 1995. Educational psychology. 6thed Boston: Allyn and Bacon.

Zhang, L, F. 2001. Thinking styles and personality types revisited. Personality and individual Differences 31 (6): 112-121. 